\title{
THE PROCESS OF DISINFECTION BY CHEMICAL AGENCIES AND HOT WATER.
}

\author{
By HARRIETTE CHICK, D.Sc. \\ Assistant, Lister Institule of Preventive Medicine.
}

(With 21 Text Figures.)

CONTENTS.

PAGE

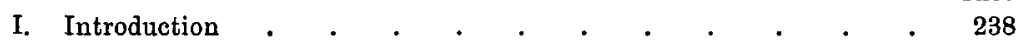

II. Disinfection with phenol . . . . . . . . . . . 240

1. Further experiments on disinfection with phenol of :

(a) B. typhosus . . . . . . . . . . 241

(b) B. coli commune . . . . . . . . . 243

(c) Staphylococcus pyogenes aureus . . . . . . 244

2. General conclusions upon disinfection with phenol . $\quad 249$

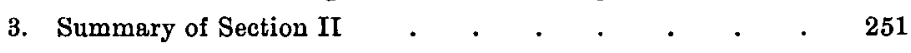

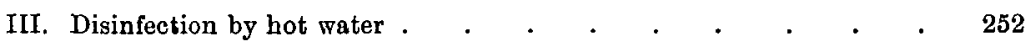

1. General remarks upon disinfection by heat . . . . 252

2. Description of the method employed and of experiments made with :

(a) B. typhosus . . . . . . . . . . 254

(b) B. coli conmune . . . . . . . . . 257

(c) B. paratyphosus . . . . . . . . . . 260

(d) Staphylococcus pyogenes albus and Staphylococcus pyogenes aureus . . . . . . . 261

(e) B. pestis . . . . . . . . . . . . 268

3. Temperature coefficient . . . . . . . . 268

4. Influence of acids and alkalis . . . . . . 272

5. Analogy between the disinfection of bacteria by hot water

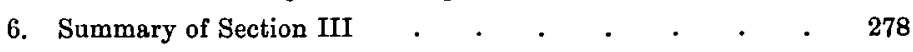

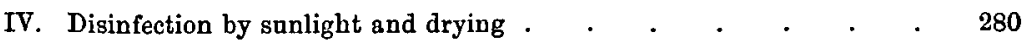

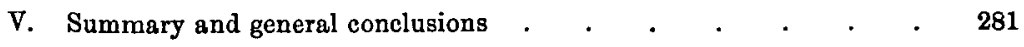




\section{INTRODUCTION.}

Krönig and Paul (1897) were the first to study the process of disinfection by making quantitative observations at intervals during its progress. Their figures showed that disinfection proceeded in an orderly manner and that the rate diminished as the number of survivors became less. Ikéda (1897) attempted to express their results by an empirical formula.

In 1907-1908, Madsen and $\mathrm{Nyman}$, and $\mathrm{H}$. Chick working simultaneously but independently at this subject, found that during the process of the disinfection of anthrax spores by chemical agents (mercuric chloride and phenol respectively) the concentration of spores remaining alive varied logarithmically with the time, and that therefore the number of anthrax spores destroyed per unit time was proportional to the number present in a unit volume of the medium at that moment. An analysis of the figures published by Krönig and Paul showed the same relationship. Tables I $a$ (H. C. 1908, p. 99) and I $b$ (K. and P. 1897, p. 26) are examples of the progress of disinfection of anthrax spores with phenol and mercuric chloride respectively; the corresponding curves in Figs. $1 a$ and $1 b$, where logarithms of concentration of survivors are plotted against time, show the logarithmic relation graphically.
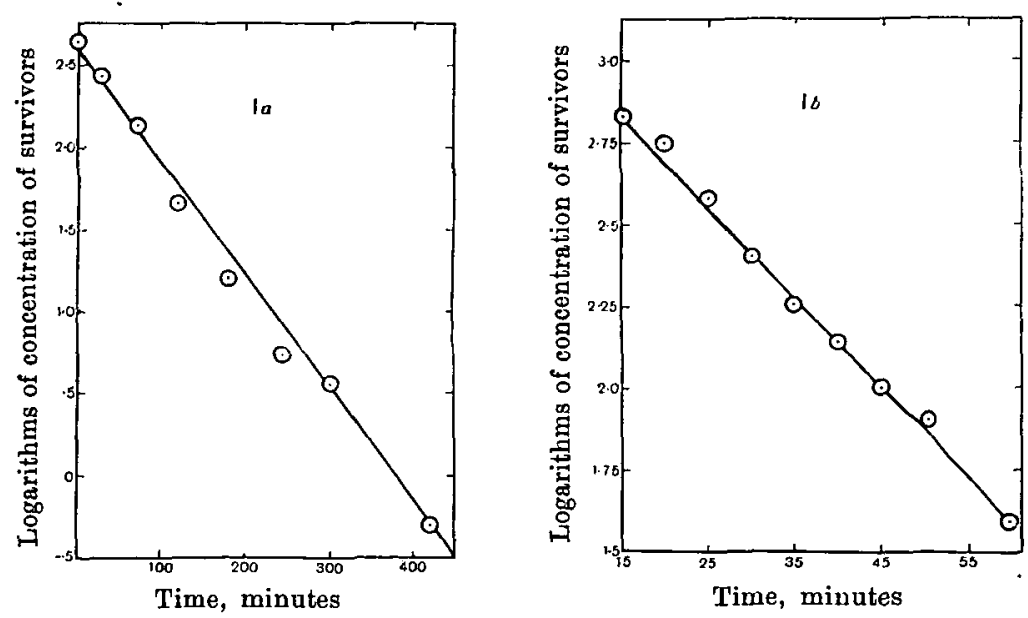

Fig. 1. (a) Disinfection of anthrax spores with $5 \%$ phenol at $33 \cdot 3^{\circ}$ C. (H. C. 1908, Table II, p. 99).

(b) Disinfection of anthrax spores with $0.11 \%$ mereuric chloride at $18^{\circ} \mathrm{C}$. (Krönig and Paul, 1897, Table IX, p. 26). 
TABLE I $a$.

Disinfection of Anthrax Spores with $5 \%$ phenol at $33.3^{\circ} \mathrm{C}$.

(See H. C. (1908), Table II, p. 99.)

\begin{tabular}{|c|c|c|c|}
\hline $\begin{array}{l}\text { Time, } \\
\text { minutes } \\
=t\end{array}$ & $\begin{array}{c}\text { Mean number of } \\
\text { bacteria surviving } \\
\text { in one drop of dis- } \\
\text { infection mixture, }=N\end{array}$ & $\log _{10} N$ & $\begin{array}{l}{ }^{*} K= \\
\frac{1}{t_{n}-t_{0}} \frac{\log N_{0}}{\log N_{n}}\end{array}$ \\
\hline $0=t_{0}$ & $439=N_{0}$ & $2 \cdot 642$ & - \\
\hline 30 & $275 \cdot 5$ & $2 \cdot 439$ & .0068 \\
\hline 75 & $137 \cdot 5$ & $2 \cdot 138$ & $\cdot 0067$ \\
\hline 120 & 46 & $1 \cdot 663$ & .0082 \\
\hline 180 & $15 \cdot 8$ & $1 \cdot 199$ & .0080 \\
\hline 246 & $5 \cdot 45$ & $\cdot 736$ & .0077 \\
\hline 300 & $3 \cdot 6$ & $\cdot 556$ & .0069 \\
\hline 420 & 0.5 & $-\cdot 301$ & $\cdot 0070$ \\
\hline
\end{tabular}

* In this and all subsequent tables, values of $K$ from the expression $\frac{1}{t_{n}-t_{0}} \log \frac{N_{0}}{N_{n}}$ are calculated with Briggs' logarithms in place of natural logarithms.

\section{TABLE I $b$.}

Disinfection of Anthrax Spores with $0.11 \%$ mercuric chloride at $18^{\circ} \mathrm{C}$.

(See Krönig and Paul (1897), Table IX, p. 26.)

\begin{tabular}{|c|c|c|c|}
\hline $\begin{array}{l}\text { Time, } \\
\text { minutes } \\
=t\end{array}$ & $\begin{array}{c}\text { Mean number of } \\
\text { bactéria surviving } \\
=N\end{array}$ & $\log _{10} N$ & $\begin{array}{c}K= \\
\frac{1}{t_{n}-t_{0}} \log \frac{N_{0}}{N_{n}}\end{array}$ \\
\hline $10=t_{0}$ & $2027=N_{0}$ & $3 \cdot 307$ & - \\
\hline 15 & 672 & $2 \cdot 827$ & .096 \\
\hline 20 & 564 & $2 \cdot 751$ & $\cdot 056$ \\
\hline 25 & 382 & $2 \cdot 582$ & .048 \\
\hline 30 & 251 & $2 \cdot 400$ & .045 \\
\hline 35 & 179 & $2 \cdot 253$ & $\cdot 042$ \\
\hline 40 & 138 & $2 \cdot 140$ & $\cdot 039$ \\
\hline 45 & 101 & $2 \cdot 004$ & $\cdot 037$ \\
\hline 50 & 80 & 1.903 & .035 \\
\hline 60 & 39 & 1.591 & $\cdot 034$ \\
\hline 70 & 6 & $\cdot 778$ & .042 \\
\hline 80 & 3 & $\cdot 477$ & .040 \\
\hline
\end{tabular}

The conclusion arrived at by Madsen and Nyman and also by myself was that if the disinfectant be present in large excess relative to the bacteria, disinfection proceeds in the same manner as a reaction of the first order, that is to say, as a unimolecular reaction, or, what amounts to the same thing, as a bimolecular reaction with one reagent in excess. 
The reason for it so doing must, apparently, be sought for in the same direction as in the case of the hydrolysis of sugar by water or the decomposition of hydrogen arsenide by heat, which are both reactions of the first order. The explanation offered by the physical chemist is that there is no permanent dissimilarity between the molecules, but that at any one time only a proportion of them is in the condition to undergo the dissociation or chemical union. This temporary increased susceptibility is believed to be occasioned by differences in the internal energy of the molecules. This interpretation has the advantage of affording a possible explanation of the influence of temperature upon the rate of reaction.

It would appear that with anthrax spores we are dealing with a population possessing but slight permanent differences in regard to their behaviour towards disinfectauts, and that the fact that the whole number is not killed off in the same time is not, as has been supposed, due to permanent variations in resistance of individuals but, as in the chemical analogies given above, occasioned by temporary energy changes in the molecules of which the bacterial proteins are composed.

In the case of B. paratyphosus, the vegetative form worked with (H. C. loc. cit.), broth cultures, obtained by successive sub-culturing at frequent intervals, behaved as anthrax spores on disinfection with phenol and the nature of the disinfection process was similarly explained. The observations made upon 24 hours' cultures of B. paratyphosus, however, indicated the existence in this case of some disturbing factor which caused the process of disinfection to depart from the simple law found to apply in the case of spores and "young" cultures.

These interpretations, put forward in the previous paper already referred to, have been criticised by Eijkman (1909), and by Hewlett (1909) in his Milroy Lectures. Although these criticisms can, I think, be met by appeal to the facts already published, they have stimulated me to perform some further experiments. These experiments will be presented first and the points raised by my critics will be dealt with subsequently.

\section{Disinfection with PHenol.}

(1) Method employed.

The method employed for studying the reaction velocity of disinfection in this instance was the same as that used in the previous paper (H. C. 1908). A measured quantity (five drops from a standard 
capillary pipette $=\cdot 08$ c.c.) from a 24 hours' broth culture of the organism selected was added to a tube containing 5 c.c. phenol solution immersed in a water bath maintained at $20^{\circ} \mathrm{C}$. This disinfection tube was fitted with a capillary pipette by means of which samples could be withdrawn and a definite number of drops taken for agar or gelatine plate cultures at successive intervals of time. Three plates were poured at each time of sampling, necessitating the help of two assistants. The sample drops were dropped into 0.5 c.c. of sterile distilled water, previously placed upon the plates; this lessened the error arising from the impossibility of pouring all three plates simultaneously. The plates were counted after 48 hours' incubation at $37^{\circ} \mathrm{C}$. in the case of agar, or after four or five days' at $20^{\circ} \mathrm{C}$. in the case of gelatine plates, and the progress of the disinfection reaction was studied by thus enumerating the surviving bacteria at successive periods of the process.

\section{(a) Experiments with B. typhosus.}

Tables II and III give the results of two experiments with B. typhosus and $0.6 \%$ phenol at $20^{\circ} \mathrm{C}$. Gelatine ${ }^{1}$ plates were used in

\section{TABLE II.}

Disinfection of B. typhosus with $0.6 \%$ phenol at $20^{\circ} \mathrm{C}$.

Exr. 8. 1. '10.

\begin{tabular}{|c|c|c|c|c|c|c|}
\hline $\begin{array}{l}\text { Time, } \\
\text { minutes } \\
=t\end{array}$ & $\begin{array}{l}\text { Amount } \\
\text { of sample } \\
\text { taken, } \\
\text { drops }\end{array}$ & $\begin{array}{l}\text { Numbers } \\
\text { on plates } \\
\text { (gelatine) }\end{array}$ & Mean & $\begin{array}{l}\text { Mean no. of } \\
\text { bacteria present } \\
\text { in } 1 \text { drop } \\
\text { disinfection } \\
\text { mixture, }=N\end{array}$ & $\log _{10} N$ & $\begin{array}{c}K= \\
\frac{1}{t_{n}-t_{0}} \log \end{array}$ \\
\hline $0.5=t_{0}$ & 1 & 236218240 & $231 \cdot 3$ & $231 \cdot 3=N_{0}$ & $2 \cdot 364$ & - \\
\hline $1 \cdot 5$ & $\mathbf{1}$ & $\begin{array}{lll}188 & 215 \quad 167\end{array}$ & 190 & 190 & $2 \cdot 279$ & $\cdot 085$ \\
\hline $2 \cdot 6$ & 1 & $160157 \quad 184$ & 167 & 167 & $2 \cdot 223$ & $\cdot 067$ \\
\hline $4 \cdot 6$ & 2 & 215242 & $228 \cdot 5$ & $114 \cdot 2$ & $2 \cdot 058$ & .075 \\
\hline $6 \cdot 6$ & 2 & $\begin{array}{lll}139 & 172 & 156\end{array}$ & $155 \cdot 7$ & $77 \cdot 8$ & $1 \cdot 891$ & $\cdot 077$ \\
\hline $10 \cdot 5$ & 3 & $\begin{array}{lll}100 & 93 & 91\end{array}$ & $94 \cdot 7$ & $31 \cdot 6$ & $1 \cdot 500$ & $\cdot 086$ \\
\hline 15 & $\mathbf{3}$ & $\begin{array}{lll}33 & 26 & 43\end{array}$ & 34 & $11 \cdot 3$ & $1 \cdot 053$ & $\cdot 090$ \\
\hline 20 & 5 & $\begin{array}{lll}14 & 14 & 8\end{array}$ & 12 & $2 \cdot 4$ & $\cdot 380$ & $\cdot 102$ \\
\hline \multirow[t]{2}{*}{30} & 10 & 43 & $3 \cdot 5$ & $\cdot 35$ & $-\cdot 456$ & $\cdot 096$ \\
\hline & & & & & Mear & an .086 \\
\hline
\end{tabular}

1 Gelatine plates were substituted for agar in all the later experiments in spite of the obvious disadvantages. There is some risk of error in the use of agar owing to the necessarily high temperature at which the plates are poured, and comparative experiments showed that higher numbers were invariably obtained by using gelatine, although the proportion remained fairly constant. 
TABLE III.

Disinfection of $B$. typhosus with $0.6 \%$ phenol at $20^{\circ} \mathrm{C}$.

Exp. 14. 1. '10.

\begin{tabular}{|c|c|c|c|c|c|c|}
\hline $\begin{array}{l}\text { Time, } \\
\text { minutes } \\
=t\end{array}$ & $\begin{array}{l}\text { Amount } \\
\text { of } \\
\text { sample } \\
\text { taken, } \\
\text { drops }\end{array}$ & $\begin{array}{l}\text { Numbers } \\
\text { on plates } \\
\text { (gelatine) }\end{array}$ & Mean & $\begin{array}{c}\text { Mean no. of } \\
\text { bacteria present } \\
\text { in } 1 \text { drop } \\
\text { disinfection } \\
\text { mixture, }=N\end{array}$ & $\log _{10} N$ & $\begin{array}{c}K= \\
\frac{1}{t_{n}-t_{0}} \log \frac{N}{N}\end{array}$ \\
\hline $0 \cdot 5=t_{0}$ & 1 & $779717 \quad 645$ & 714 & $714=N_{0}$ & $2 \cdot 854$ & - \\
\hline $1 \cdot 5$ & 1 & 584571 & $577 \cdot 5$ & $577 \cdot 5$ & $2 \cdot 762$ & .092 \\
\hline 2.5 & 1 & $406 \quad 526 \quad 451$ & 461 & 461 & $2 \cdot 664$ & .095 \\
\hline 4.5 & 1 & $313 \quad 215 \quad 288$ & 272 & 272 & $2 \cdot 435$ & $\cdot 105$ \\
\hline $6 \cdot 5$ & 1 & $\begin{array}{llll}136 & 149 & 145\end{array}$ & $143 \cdot 3$ & $143 \cdot 3$ & $2 \cdot 156$ & $\cdot 116$ \\
\hline 10 & 2 & $47 \quad 162 \quad 155$ & $121 \cdot 3$ & $60 \cdot 6$ & $1 \cdot 782$ & $\cdot 113$ \\
\hline \multirow[t]{2}{*}{20} & 5 & 35 & -1 & $4 \cdot 48$ & $\cdot 651$ & $\cdot 113$ \\
\hline & 10 & $23 \quad 54$ & & & \multicolumn{2}{|c|}{ Meen $\cdot 106$} \\
\hline
\end{tabular}

both experiments. Disinfection, as in the case of anthrax spores, proceeded so that the number of survivors in unit volume varied logarithmically with the time; the logarithms of these numbers, when plotted against time, also gave straight lines (Fig. 2). The velocity constant, $K\left(=\frac{I}{t_{n}-t_{0}} \log \frac{N_{0}}{N_{n}}\right)$, calculated from the experimental numbers, is given in the last column of either table, and shows fair constancy in value.

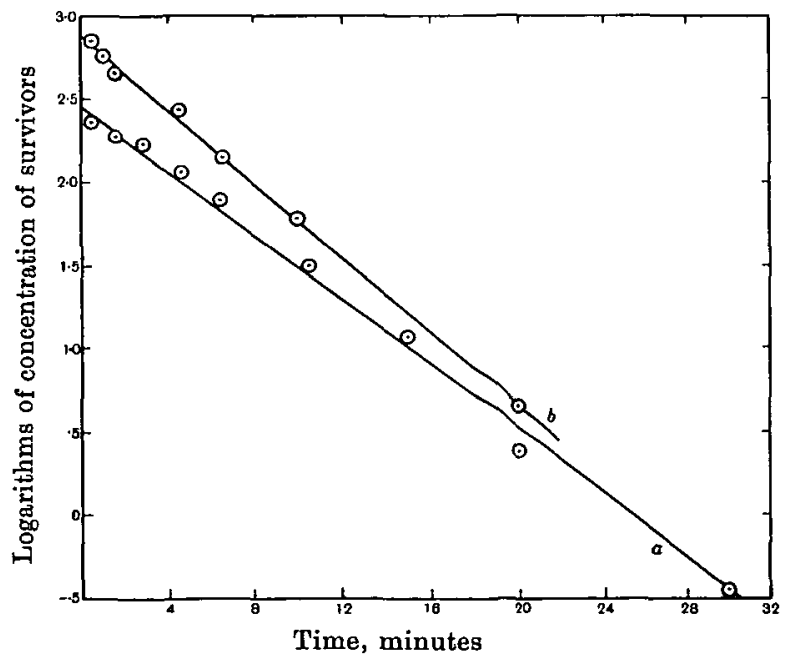

Fig. 2. Disinfection of B. typhosus with $0.6 \%$ phenol at $20^{\circ} \mathrm{C}$.
(a) Exp. 8. 1. '10, Table II.
(b) Exp, 14. 1. '10, Table III. 


\section{Н. Снтск}

(b) Experiments with $B$. coli commune.

Tables IV and $\mathrm{V}$ give the results of two experiments with $B$. coli commune and $0.5 \%$ phenol at $20^{\circ} \mathrm{C}$, in the one case agar and in the other gelatine plates being used. 24 hours' cultures in broth at $37^{\circ} \mathrm{C}$.,

\section{TABLE IV.}

Disinfection of B. coli commune with $0.5 \%$ phenol at $20^{\circ} \mathrm{C}$. Exp. 15. 2. '10.

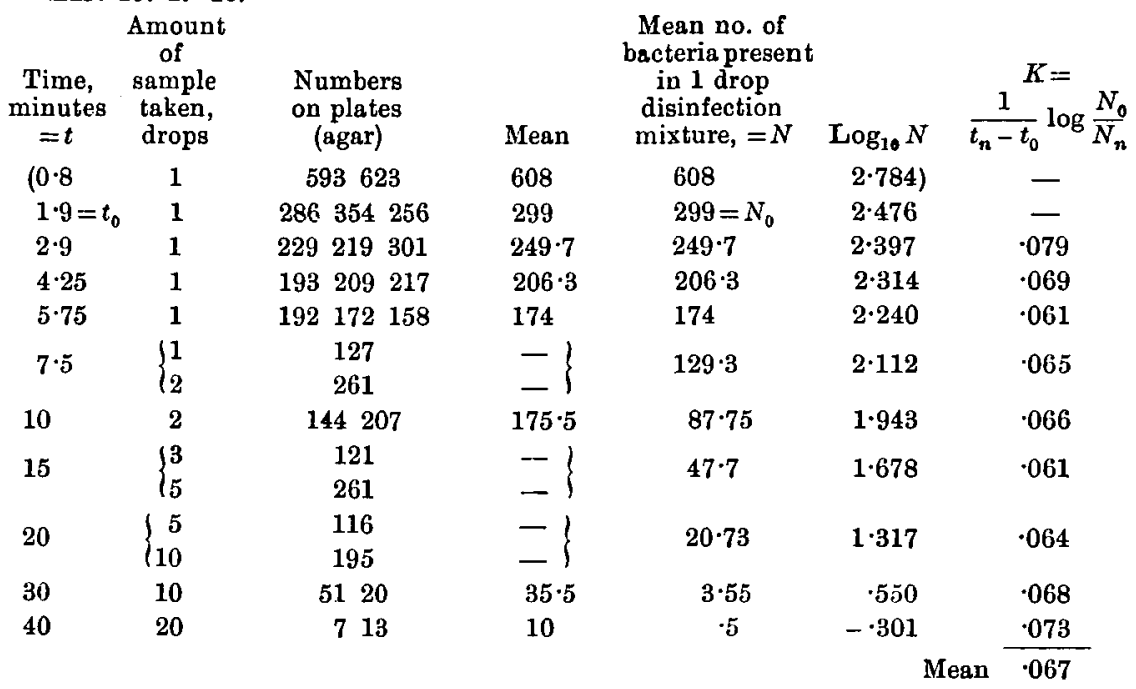

TABLE V.

Disinfection of $B$. coli commune with $0.5 \%$ phenol at $20^{\circ} \mathrm{C}$.

Exp. 21. 3. '10.

\begin{tabular}{|c|c|c|c|c|c|c|}
\hline $\begin{array}{l}\text { Time, } \\
\text { minutes } \\
=t\end{array}$ & $\begin{array}{c}\text { Amount } \\
\text { of } \\
\text { sample } \\
\text { taken, } \\
\text { drops }\end{array}$ & $\begin{array}{l}\text { Numbers } \\
\text { on plates } \\
\text { (gelatine) }\end{array}$ & Mean & $\begin{array}{l}\text { Mean no. of } \\
\text { bacteria present } \\
\text { in } 1 \text { drop } \\
\text { disinfection } \\
\text { mixture, }=N\end{array}$ & $\log _{10} N$ & $\begin{array}{c}K= \\
\frac{1}{t_{n}-t_{0}} \log \frac{N}{N}\end{array}$ \\
\hline$(0.6$ & 1 & $\begin{array}{lll}645 & 623 & 648\end{array}$ & 639 & 639 & $2.805)$ & \\
\hline$(1.5$ & 1 & $\begin{array}{llll}565 & 564 & 639\end{array}$ & 589 & 589 & $2 \cdot 770)$ & \\
\hline $2 \cdot 5=t_{0}$ & 1 & 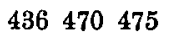 & 460 & $460=N_{0}$ & $2 \cdot 663$ & - \\
\hline $3 \cdot 75$ & 1 & $\begin{array}{llll}425 & 395 & 364\end{array}$ & 395 & 395 & $2 \cdot 597$ & $\cdot 053$ \\
\hline 5 & 1 & $\begin{array}{llll}340 & 329 & 351\end{array}$ & 340 & 340 & $2 \cdot 531$ & .053 \\
\hline 7 & 2 & $\begin{array}{lll}493 & 513 & 498\end{array}$ & 501 & 250 & $2 \cdot 398$ & $\cdot 059$ \\
\hline 10 & $\left\{\begin{array}{r}2 \\
10\end{array}\right.$ & $\begin{array}{rr}387 & 416 \\
2080 & 1830\end{array}$ & $-\}$ & 196 & $2 \cdot 292$ & $\cdot 049$ \\
\hline 15 & 2 & $204 \quad 273$ & 238 & 119 & $2 \cdot 075$ & $\cdot 047$ \\
\hline \multirow[t]{2}{*}{20} & 20 & 16701780 & 1725 & $86 \cdot 2$ & $1 \cdot 935$ & $\cdot 042$ \\
\hline & & & & & ear & .051 \\
\hline
\end{tabular}


made from a stock agar culture grown at room temperature, again served as the material to be disinfected and the method was exactly as above described.

The results are similar to those obtained in the case of $B$. typhosus; as disinfection proceeds a logarithmic relation is approximately maintained between the time of disinfection and the concentration of surviving bacteria.

In some cases for a very short period (usually less than two minutes) at the beginning of the experiment there was some irregularity. Numbers counted during this period are not plotted in Fig. 3 or used for calculating the velocity constants in Tables IV and V. I am inclined to attribute this to a difficulty with this species in obtaining perfect mixing and accurate sampling during the first moments of an experiment. The variation was not consistent in one sense, in some cases the number of bacteria counted was larger, in others smaller than was to be expected. Eijkman's (1909) results which differ from the above will be referred to later (see p. 249).

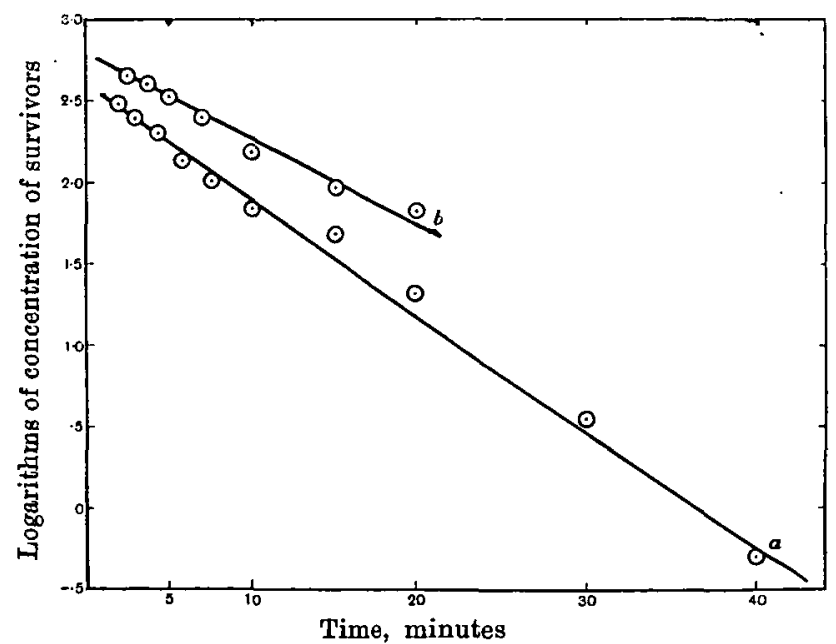

Fig. 3. Disinfection of $B$. coli commune with $0.5 \%$ phenol at $20^{\circ} \mathrm{C}$.

(a) Exp. 15. 2. '10, Table IV. (b) Exp. 21. 3. '10, Table V.

(c) Staphylococcus pyogenes aureus.

Disinfection proceeds logarithmically except for a period at the beginning, during which disinfection is extremely slow. This period of lag lasted in all cases for four minutes, see Figs. 4 and 5 , and was 
consistently present in contradistinction to the irregularity frequently noticed in the case of $B$. coli commune. At the end of this period disinfection proceeded in approximate accordance with the logarithmic law.

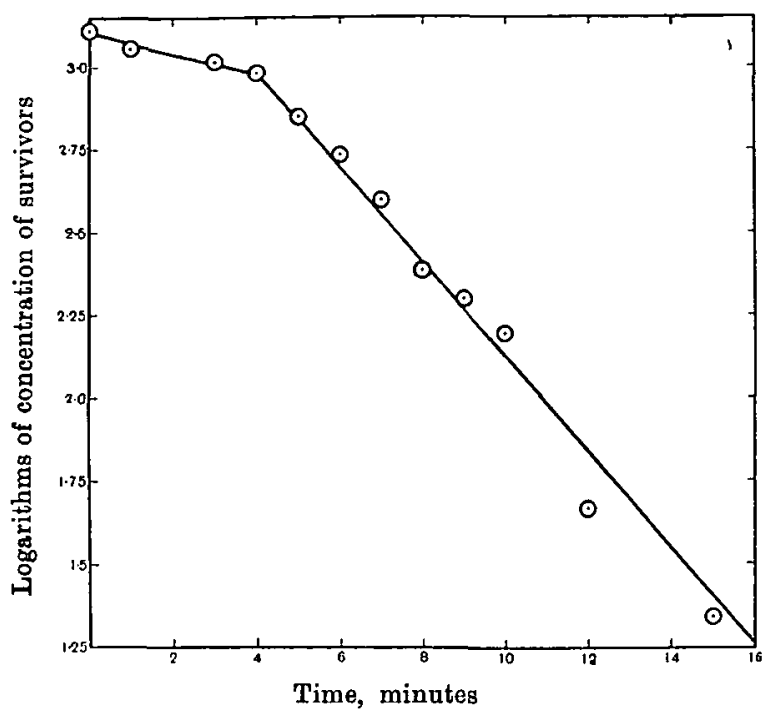

Fig. 4. Disinfection of Staphylococcus pyogenes aureus with $0.6 \%$ phenol at $20^{\circ} \mathrm{C}$. (Exp. 6. 4. '09, Table VI.)

TABLE VI.

Disinfection of Staphylococcus pyogenes aureus with $0.6 \%$ phenol at $20^{\circ} \mathrm{C}$. Exp. 6. 4. '09.

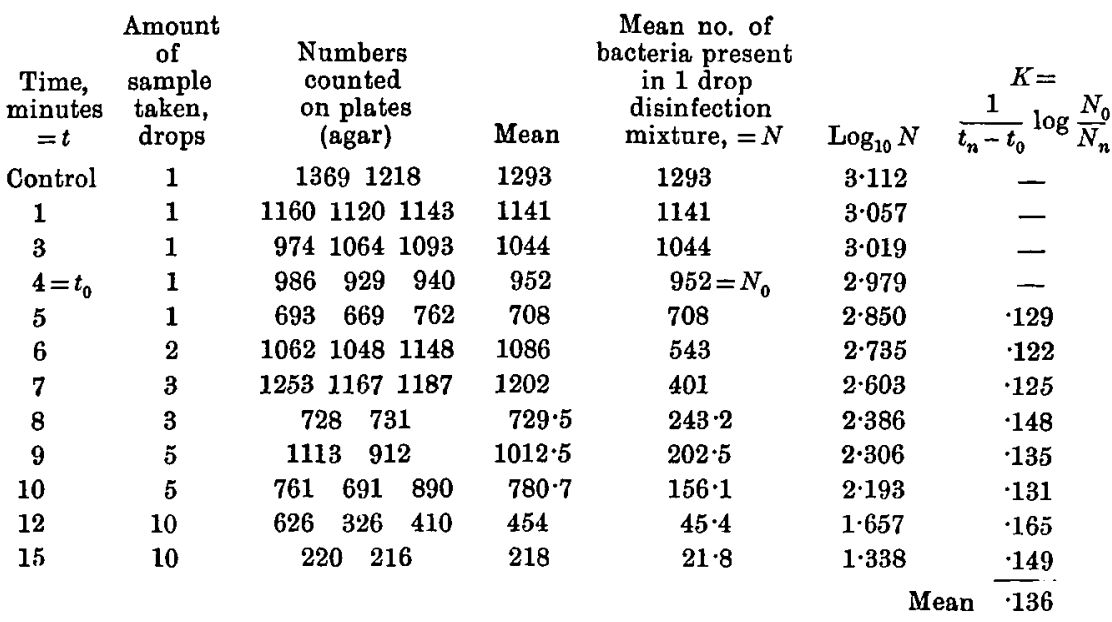




\section{TABLE VII.}

Disinfection of Staphylococcus pyogenes aureus with $0.6 \%$ phenol at $20^{\circ} \mathrm{C}$.

Exp. 16. 3. '09.

\begin{tabular}{|c|c|c|c|c|c|c|}
\hline $\begin{array}{l}\text { Time, } \\
\text { minutes } \\
=t\end{array}$ & $\begin{array}{c}\text { Amount } \\
\text { of } \\
\text { sample } \\
\text { taken, } \\
\text { drops }\end{array}$ & $\begin{array}{l}\text { Numbers } \\
\text { counted } \\
\text { on plates } \\
\text { (agar) }\end{array}$ & Mean & $\begin{array}{l}\text { Mean no. of } \\
\text { bacteria present } \\
\text { in } 1 \text { drop } \\
\text { disinfection } \\
\text { mixture, }=N\end{array}$ & $\log _{10} N$ & $\begin{array}{c}\frac{1}{t_{n}-t_{n}} \log \\
\text {. }\end{array}$ \\
\hline Control & 1 & 12221140 & 1180 & 1180 & $3 \cdot 072$ & - \\
\hline 1 & 1 & $\begin{array}{lll}1005 & 978 & 1011\end{array}$ & 998 & 998 & $2 \cdot 999$ & - \\
\hline 2 & 1 & $958 \quad 995 \quad 944$ & 966 & 966 & $2 \cdot 985$ & - \\
\hline 3 & 1 & $\begin{array}{lll}794 & 878 & 889\end{array}$ & 854 & 854 & $2 \cdot 931$ & - \\
\hline $4=t_{0}$ & 2 & $14981400 \quad 1570$ & 1489 & $744=N_{0}$ & $2 \cdot 872$ & 一 \\
\hline $5 \cdot 1$ & 3 & $20391882 \quad 1649$ & 1857 & 619 & $2 \cdot 792$ & 073 \\
\hline 7 & 8 & $2723 \quad 25862100$ & 2469 & 309 & $2 \cdot 490$ & $\cdot 127$ \\
\hline 10 & 10 & $961 \quad 1172 \quad 1550$ & 1228 & $122 \cdot 8$ & $2 \cdot 089$ & $\cdot 130$ \\
\hline \multirow[t]{2}{*}{15} & $\left\{\begin{array}{r}10 \\
6\end{array}\right.$ & $\begin{array}{c}315 \quad 247 \\
187\end{array}$ & $-\}$ & $29 \cdot 1$ & $1 \cdot 464$ & $\cdot 128$ \\
\hline & & & & & & ean $\cdot 114$ \\
\hline
\end{tabular}

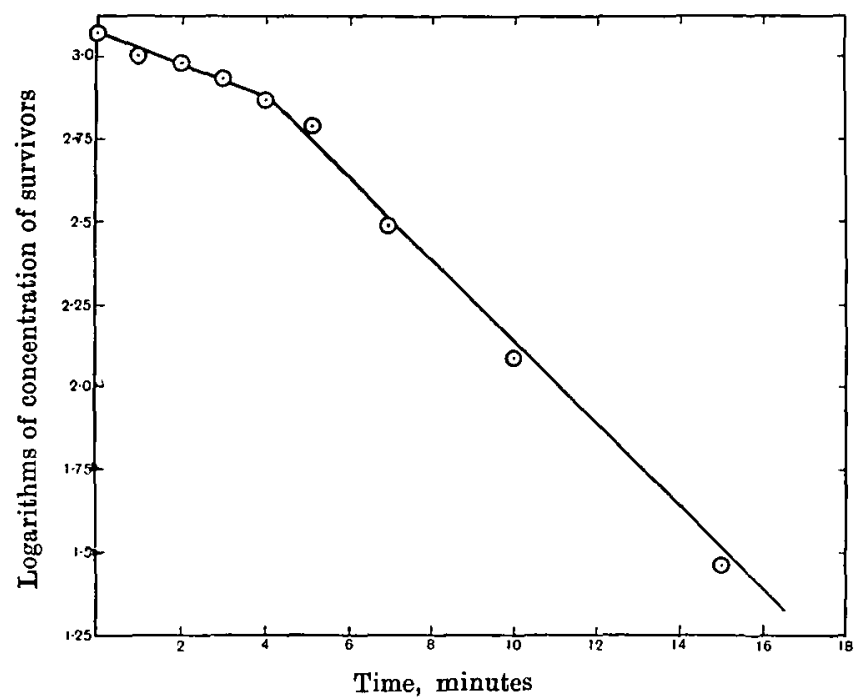

Fig. 5. Disinfection of Staphylococcus pyogenes aureus with $0.6 \%$ phenol at $20^{\circ} \mathrm{C}$. (Exp. 16. 3. '09, Table VIr.)

The results of two experiments with Staphylococcus py. aur. and $0.6 \%$ phenol at $20^{\circ} \mathrm{C}$. are given in Tables VI and VII. For reckoning the value of the velocity constant in these tables the initial concentration of bacteria is taken as that obtaining at the end of the "period of 
lag," as determined from the curves in Figs. 4 and 5 respectively, where logarithms of concentration of survivors are plotted against time. The results of two additional experiments are given in Table VIII.

\section{TABLE VIII.}

Disinfection of Staphylococcus pyogenes aureus with $0.6 \%$ phenol at $20^{\circ} \mathrm{C}$.

Exp. I, 30. 3. '09.

\begin{tabular}{ccccccc}
$\begin{array}{c}\text { Amount } \\
\text { of } \\
\text { Time, } \\
\text { minutes } \\
=t\end{array}$ & $\begin{array}{c}\text { Numbers } \\
\text { taken, } \\
\text { drops }\end{array}$ & $\begin{array}{c}\text { counted } \\
\text { on plates } \\
\text { (agar) }\end{array}$ & Mean & $\begin{array}{c}\text { Mean no. of } \\
\text { bacteria present } \\
\text { in 1 drop } \\
\text { disinfection } \\
\text { mixture, }=N\end{array}$ & $\log _{10} N$ & $\frac{1}{t_{n}-t_{0}} \log \frac{N_{0}}{N_{n}}$ \\
3 & 1 & 310 & 310 & 310 & $2 \cdot 491$ & - \\
$4=t_{0}$ & 1 & 284224236 & 248 & $248=N_{0}$ & $2 \cdot 394$ & - \\
5 & 1 & 120128127 & 125 & 125 & $2 \cdot 097$ & $\cdot 30$ \\
6 & 1 & 107109 & 108 & 108 & $2 \cdot 033$ & $\cdot 18$ \\
7 & 2 & $95 \quad 88$ & $91 \cdot 5$ & $45 \cdot 7$ & $1 \cdot 660$ & $\cdot 24$ \\
8 & 2 & 6347 & 55 & $27 \cdot 5$ & $1 \cdot 439$ & $\cdot 24$ \\
9 & 2 & $36 \quad 36$ & 36 & 18 & $1 \cdot 255$ & $\cdot 23$ \\
10 & 3 & 131433 & 20 & $6 \cdot 66$ & $0 \cdot 823$ & $\cdot 26$ \\
12 & 5 & 2625 & $25 \cdot 5$ & $5 \cdot 1$ & $\cdot 708$ & $\cdot 21$ \\
15 & 5 & $1719 \quad 18$ & 18 & $3 \cdot 6$ & $\cdot 556$ & $\cdot 17$ \\
\hline
\end{tabular}

Exp. II, 13. 3. '09.

\begin{tabular}{|c|c|c|c|c|c|c|c|c|}
\hline 1 & 1 & 663 & 641 & 633 & 646 & 646 & $2 \cdot 810$ & - \\
\hline $3=t_{0}$ & 1 & 246 & 260 & 254 & 253 & $253=N_{0}$ & $2 \cdot 403$ & - \\
\hline 5 & 1 & 42 & 49 & 41 & 44 & 44 & $1 \cdot 643$ & $\cdot 38$ \\
\hline 7 & 2 & 40 & 24 & 20 & 28 & 14 & $1 \cdot 146$ & $\cdot 31$ \\
\hline 10 & 2 & 4 & 6 & 7 & $5 \cdot 66$ & $2 \cdot 83$ & $\cdot 452$ & 28 \\
\hline \multicolumn{9}{|c|}{ Mean $\cdot 32$} \\
\hline
\end{tabular}

In Table IX are given the results of two experiments with Staphylococcus py. aur. and $0.6 \%$ phenol, in which comparison is made between the disinfection of bacteria grown at $37^{\circ} \mathrm{C}$. (Exp. $a$ ) and bacteria grown at $42^{\circ} \mathrm{C}$. (Exp. $b$ ), the conditions of experiment being otherwise identical. Disinfection in the first case was consistent with the experiments described above, but the bacteria grown at the higher temperature displayed as a whole a greatly increased resistance, and disinfection was so slow that it was impossible to study it within the time of the experiment. A similar phenomenon was noticed in the case of disinfection of B. typhosus with phenol by Rideal and Walker (1903, p. 431), and by Martin and the author (1908, p. 661). 
TABLE IX.

Disinfection of Staphylococcus pyogenes aureus with $0.6 \%$ phenol at $20^{\circ} \mathrm{C}$.

Experiments to show difference in resistance of a culture grown at $37^{\circ} \mathrm{C}$. and one grown at $42^{\circ} \mathrm{C}$.

ExP. 23. 3. '09. (a) Culture grown at $37^{\circ} \mathrm{C}$.

\begin{tabular}{|c|c|c|c|c|c|c|}
\hline $\begin{array}{l}\text { Time, } \\
\text { minutes } \\
=t\end{array}$ & $\begin{array}{c}\text { Amount } \\
\text { of } \\
\text { sample } \\
\text { taken, } \\
\text { drops }\end{array}$ & $\begin{array}{l}\text { Numbers } \\
\text { counted } \\
\text { on plates } \\
\text { (agar) }\end{array}$ & Mean & $\begin{array}{l}\text { Mean no. of } \\
\text { bacteria present } \\
\text { in 1 drop } \\
\text { disinfection } \\
\text { mixture, }=N\end{array}$ & $\log _{10} N$ & $\begin{array}{c}K= \\
\frac{1}{t_{n}-t_{0}} \log \end{array}$ \\
\hline Control & 1 & $656 \quad 679$ & 667 & 667 & $2 \cdot 824$ & - \\
\hline 1 & 1 & $600 \quad 709554$ & 621 & 621 & $2 \cdot 793$ & - \\
\hline 2 & 1 & $659 \quad 616 \quad 516$ & 597 & 597 & $2 \cdot 776$ & - \\
\hline 3 & 1 & $587 \quad 616 \quad 613$ & 605 & 605 & $2 \cdot 782$ & - \\
\hline $4=t_{0}$ & 1 & $510544 \quad 460$ & 505 & $505=N_{0}$ & $2 \cdot 703$ & - \\
\hline 5 & 2 & 765932 & 848 & 424 & $2 \cdot 627$ & .076 \\
\hline 7 & 3 & $\begin{array}{lll}1115 & 847 & 1017\end{array}$ & 993 & 331 & 2.520 & .091 \\
\hline \multirow[t]{2}{*}{10} & $\left\{\begin{array}{r}10 \\
8\end{array}\right.$ & $\begin{array}{c}14881410 \\
1317\end{array}$ & -3 & $150 \cdot 5$ & $2 \cdot 177$ & .088 \\
\hline & & & & & \multicolumn{2}{|r|}{.085} \\
\hline
\end{tabular}

(b) Culture grown at $42^{\circ} \mathrm{C}$.

$\begin{array}{ccccccc}\text { Control } & 1 & 116 & 116 & 116 & 2 \cdot 064 & - \\ 2 & 1 & 80102101 & 94 \cdot 3 & 94 \cdot 3 & 1 \cdot 975 & - \\ 3 & 1 & 11791 & 104 & 104 & 2 \cdot 017 & - \\ 5 & 2 & 171190156 & 172 \cdot 3 & 86 \cdot 1 & 1 \cdot 935 & - \\ 7 & 3 & 231255265 & 250 & 83 \cdot 4 & 1 \cdot 921 & - \\ 10 & 10 & 825768843 & 812 & 81 \cdot 2 & 1 \cdot 910 & -\end{array}$

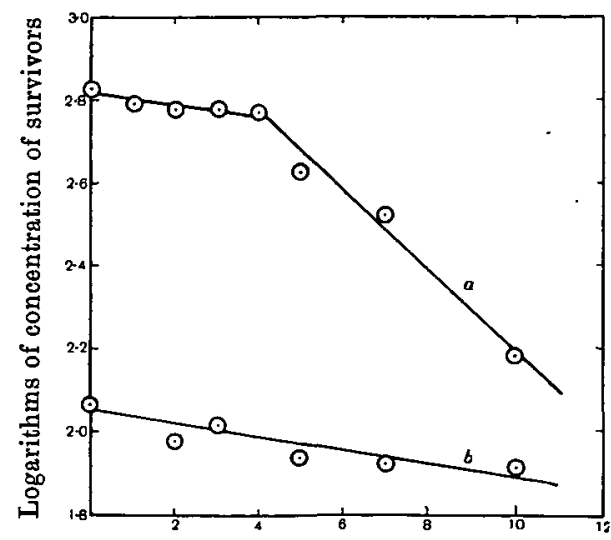

Time, minutes

Fig. 6. Disinfection of Staphylococcus pyogenes aureus with $0.6 \%$ phenol at $20^{\circ} \mathrm{C}$. (Table IX.)

(a) 24 hours' culture at $37^{\circ} \mathrm{C} . \quad$ (b) 24 hours' culture at $42^{\circ} \mathrm{O}$. 
(2) General conclusions upon disinfection with phenol.

Disinfection with phenol may in general be considered to proceed in accordance with a logarithmic law so that the concentration of survivors varies logarithmically with time, or, in other words, the rate of disinfection at any moment is proportional to the concentration of surviving bacteria $\left(-\frac{d n}{d t}=K n\right)$.

Of the species worked with, anthrax spores, B. typhosus, and cultures of $B$. paratyphosus obtained by successive sub-culturing after short periods of growth, may be cited as proof of this assertion, without further remark. In my opinion, B. coli commune and Staphylococcus pyogenes aureus (if we allow for a short "period of lag" at the beginning of disinfection) may be added to this list.

Eijkman, however, came to the conclusion that the rate of disinfection of B. coli commune by phenol (1909) or hot water (1908) was not proportional to the concentration of survivors, except possibly for a short period in the middle of the disinfection, and that a much slower rate obtained not only at the beginning but also at the end. The "period of lag" constantly present at the start was called by him a "period of incubation." This is contrary to my own experience of $B$. coli, which, whether disinfected by phenol or by heat (see below), I bave found to die at a rate approximately proportional to the concentration of survivors. Slight discrepancies occur at the beginning of disinfection, but these, I think, are attributed to error in sampling. My experience confirms that of Eijkmann (1908, p. 17, and 1909, p. 6), who had great difficulty in obtaining uniformity in cultures of $B$. coli.

In the case of Staphylococcus and 24 hours' cultures of B. paratyphosus the departire from the logarithmic law at the beginning of disinfection is of a different character. The invariable "incubation period" in the first case, and the invariable preliminary rush in the second, are evidently realities and must be attributed to some idiosyncracy of the species in question. With Staphylococcus, after about 4 minutes, disinfection proceeds in an orderly manner so that the delay is possibly due to a slow permeability of the bacterial envelope to phenol.

In the case of 24 hours' cultures of B. paratyphosus (see H. C. 1908, p. 109) the surviving bacteria decrease in number more rapidly at first than would be the case if the rate of disinfection were simply proportional to the concentration of bacteria at the moment, and a suggested

Journ. of Hyg. $x$ 
explanation has already been put forward. This explanation has been criticised in the meantime by Hewlett (1909), so that a few further remarks may be permitted. The departure from the logarithmic law was found to be minimised by experimenting with material obtained by successively sub-culturing a small amount of a broth culture into fresh broth every $2-3$ hours; in this case disinfection proceeded in a more regular manner and at the slower rate. This is shown in Fig. 7, which illustrates two ex periments with B. paratyphosus and $0.6 \%$ phenol (loc. cit. Tables VII and XII), one made with a 24 hours' culture and the other with material which had been successively sub-cultured three times at three hours' intervals. In the former case logarithms of concentration of living bacteria, plotted against time, give a curve; in the latter case, however, disinfection is more nearly logarithmic throughout, the experimental points lie on a straight line and the velocity constant has an approximately constant value.

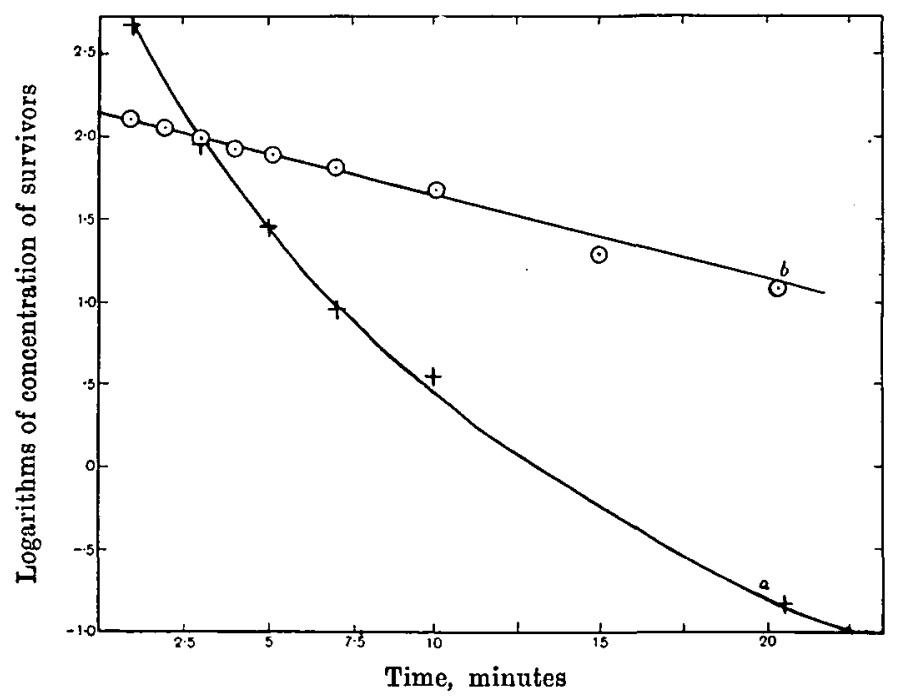

Fig. 7. (a) Disinfection of 24 hours' culture of $B$. paratyphosus with $0.6 \%$ phenol at $21^{\circ}$ C. (H. C. 1908 , Table VII.)

(b) Disinfection of 3 hours' culture (3rd generation of 3 hours' cultures) of B. paratyphosus with $0.6 \%$ phenol at $20^{\circ}$ C. (H. C. 1908, Table XII.)

Hewlett (loc. cit. p. 50), after an analysis, among others, of the tables from which these curves are drawn, "can only see a slight balance in favour of the 'young' cultures giving a constant less variable than the constant obtained with 24 hours' cultures." Hewlett's treatment of 
these data is not quite legitimate. The tables he compares are not strictly comparable, the times at which samples were taken being different in the different cases. Comparison of curves, on the other hand, in which logarithms of concentration of surviving bacteria are plotted against time, is unexceptionable. From experiments with 24 hours' cultures of B. paratyphosus a series of curved lines are obtained, whereas from experiments with successively cultured material the lines are approximately straight, see Fig. 7 .

The following interpretation was suggested to account for this apparent anomaly. Whereas in the case of anthrax spores and other species, where disinfection proceeds logarithmically, we may suppose temporary differences in resistance to disinfectants to exist among the individual bacteria (see also pp. 240 and 282), in 24 hours' cultures of B. paratyphosus we must suppose in addition the existence of permanent differences in resistance among the individuals, these differences to be in some way bound up with the "age" of the culture.

In my previous paper this was perhaps not very satisfactorily expressed, which may account for some misunderstanding. The age of individuals, as long as multiplication is regularly maintained during growth of a culture, would probably be the same in all cultures of whatever history, provided the temperature of incubation were the same. But a difference might exist between the population of a 3 hours' and a 24 hours' culture, owing to the fact that in the latter case the culture medium had altered in composition by the time the last multiplication had taken place, as a result of the large amount of growth it had already sustained ${ }^{1}$. In such a sense one may imagine differences to exist between "old" and "young" cultures. Whatever may be the correct manner of expression, it seerns that the majority of the individuals in 24 hours' cultures of $B$. paratyphosus have a permanently weakened resistance to disinfectants, which must be distinguished from, and which they possess in addition to, those temporary differences in resistance by which $I$ account for the logarithmic nature of disinfection in the ideal case.

\section{(3) Summary of Section II.}

1. Further experimeutal evidence is adduced to show that disinfection with phenol proceeds in accordance with a logarithmic law,

1 In my experiments 24 hours' cultures would seem to have attained the limit of growth, from the approximately constant number of bacteria they contained. 
in a manner analogous to that of a reaction of the first order, so that the velocity of disinfection at any moment is proportional to the concentration of surviving bacteria $\left(-\frac{d n}{d t}=K n\right)$.

Experiments have been made with

(a) B. typhosus,

(b) B. coli commune,

(c) Staphylococcus pyogenes aureus,

and compared with those made with anthrax spores and B.paratyphosus, which have been published previously.

2. In the case of Staphylococcus py. aur. there is invariably a short period (4 minutes with $0.6 \%$ phenol) at the beginning of disinfection, when the disinfectant has little or no effect, after which disinfection proceeds in the normal manner. The suggestion is made that it is due to time taken for penetration of the bacterial envelope by the disinfectant.

3. In the case of 24 hours' cultures of $B$. paratyphosus, where disinfection proceeds at first at a rate which is in excess of what it would be if proportional only to the concentration of survivors, the majority of the individuals possess a permanently lessened resistance to the disinfectant. It is suggested, in amplification of a suggestion put forward in a previous paper, that this may be caused by exhaustion of the medium in which the bacteria bave been grown. Cultures produced by successive sub-culture after short intervals of time show approximate conformity to the logarithmic law.

\section{THE PROCESS OF DISINFECTION BY HOT WATER.}

(1) General remarks upon disinfection by heat.

In disinfection by heat it is possible that three entirely different processes may be at work:

(1) the direct effect of heat upon the proteins of the bacteria,

(2) the effect, possibly hydrolytic, of water upon these proteins at high temperatures,

(3) desiccation of the organisms.

In sterilisation of bacteria by dry heat a combination of (1) with (2) or possibly with (2) and (3) may occur. The germicidal action of hot water at temperatures of $45^{\circ} \mathrm{C}$. to $55^{\circ} \mathrm{C}$., however, presents a very suitable subject for the study of the simplest disinfection process. For, from the analogous behaviour of proteins and enzymes, when treated with 


\section{H. CHICK}

hot water, it would appear to present an uncomplicated instance of the second effect.

Madsen and Nyman (1907) investigated the rate at which anthrax spores dried in the air upon the surface of garnets (method of Krönig and Paul, 1897) were killed when placed in glass tubes and immersed in an oil bath at $100^{\circ} \mathrm{C}$. and $110^{\circ} \mathrm{C}$. respectively. At intervals one tube of garnets was removed, the garnets shaken in a measured quantity of water and plate cultures made. Their observations do not afford convincing evidence that, under these conditions, disinfection proceeds in accordance with a logarithmic law, but the authors, considering the roughness of the experimental method, seem satisfied with the agreement between calculated and observed values.

The following experiments refer to the effect of water at temperatures from $45^{\circ} \mathrm{C}$. to $55^{\circ} \mathrm{C}$., this method of experiment having been adopted in order to avoid some of the complications mentioned above.

\section{(2) Method employed.}

A wide mouthed test tube, capacity about 50 c.c., was fitted with a cork having two holes, into each of which a small piece of glass tubing had been fitted. The smaller glass tube $A$ (see Fig. 8) acted as a bearing for the stirrer $C$ which was attached to a bicycle hub by a

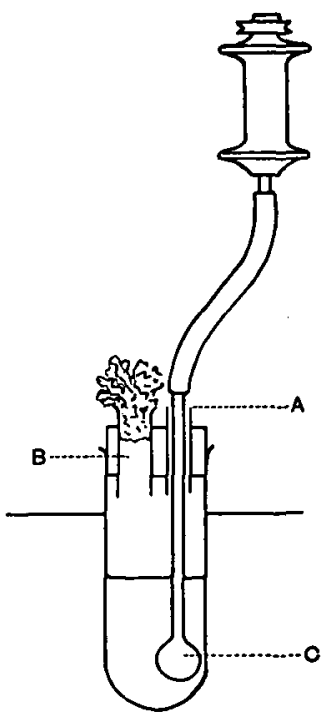

Fig. 8. 
piece of india-rubber tubing. The bicycle hub had a small pulley at its upper end round which a cord passed to the shafting. The second tube, $B$, closed with a cotton wool plug, was used for adding the bacteria and for the withdrawal of the samples.

The whole apparatus being previously sterilised, 20 c.c. of sterile distilled water was placed in the tube and the whole allowed to remain in the bath sufficiently long to acquire the necessary temperature. A 24 hours' broth culture of the particular organism, grown at $37^{\circ} \mathrm{C}$., was diluted about five to ten times, and at a given moment a small quantity of the diluted culture was introduced through the small tube $B$. At suitable times samples were withdrawn with sterilised pipettes, placed in separate small sterilised tubes and allowed to cool immediately.

At the conclusion of the experiment, plates were poured with measured quantities of the liquid in the series of tubes, smaller quantities $(0.02$ c.c.) from the earlier samples and larger quantities $(0.2$ to 0.4 c.c. $)$ from the later samples.

The experiments were preferably so arranged that the disinfection tube contained about 500 to 2000 organisms per standard drop (25,000 to 100,000 per c.c.) at the start and samples were usually taken until there were less than 10 per drop.

The character of the disinfection process and its velocity at different temperatures was studied in the case of the following organisms :

(a) B. typhosus,

(b) B. coli commune,

(c) B. paratyphosus,

(d) Staphylococcus pyogenes albus and Staphylococcus pyogenes aureus,

(e) B. pestis.

\section{(a) Experiments with B. typhosus.}

Experiments with 24 hours' cultures of $B$. typhosus were made over a series of temperatures from $49^{\circ} \mathrm{C}$. to $54^{\circ} \mathrm{C}$. The results of two experiments at $54.15^{\circ} \mathrm{C}$. and $49^{\circ} \mathrm{C}$. respectively are given in Table $\mathrm{X}$ and graphically expressed in Fig. 9 ; the results of two further experiments at $52^{\circ} \mathrm{C}$. and $52 \cdot 1^{\circ} \mathrm{C}$. are given in Table XI.

Disinfection proceeded according to the usual rule, approximately constant values were obtained for the velocity constant $K\left(=\frac{1}{t_{n}-t_{0}}\right.$ $\log \left(\frac{N_{0}}{N_{n}}\right)$ and approximately straight lines were obtained on plotting 
time against logarithms of numbers of survivors present in unit volume. The first enumeration in the experiment at $49^{\circ} \mathrm{C}$. (2008 bacteria per drop at 0.28 minutes) is out of line with the other determinations, and has been disregarded on the ground that, owing to imperfect mixing in so short a time, much stress should not be laid upon the result of the analysis of a sample taken during the first 20 seconds after addition of the bacteria. If this determination is included and used in the calculation of the values for the velocity constant, disinfection will apparently proceed at an excessive rate during the first minute $(K=308)$. For the reason given above it is hard to say whether the phenomenon is a reality or not. In other experiments there is, however, also a fall, though slight, in the value of $K$ as disinfection proceeds, see Exp. II, Table X, and Exps. I and II, Table XI.

\section{TABLE X.}

Disinfection of B. typhosus with hot water.

Exr. I, 9. 6. '09. Temperature $49^{\circ} \mathrm{C}$.

$\begin{array}{cc}\begin{array}{c}\text { Amount } \\ \text { of } \\ \text { minutes } \\ =t\end{array} & \begin{array}{c}\text { sample } \\ \text { taken, } \\ \text { drops }\end{array} \\ 0 \cdot 28 & 1 \\ 1 \cdot 0=t_{0} & 1 \\ 2 \cdot 05 & 1 \\ 3 & 3 \\ 4 & 4 \\ 5 & \left\{\begin{array}{r}1 \\ 10\end{array}\right. \\ 7 & \left\{\begin{array}{r}6 \\ 10 \\ 10\end{array}\right. \\ 15 & \left\{\begin{array}{l}10 \\ 20\end{array}\right. \\ 20 & \left\{\begin{array}{c}9 \\ 10 \\ 20\end{array}\right.\end{array}$

Numbers
counted
on plates

(agar)

188121222022

12981098

$\begin{array}{lll}914 \quad 769 & 1093\end{array}$

178222462770

194725222038

449

51804640

1788

28002940

111310671204

211

514

30

28
Mean no. of bacteria present in 1 drop disinfection mixture, $=N$

2008

$1198=N_{0}$

925

755

542

488

289

$112 \cdot 8$

$24 \cdot 2$

3
$K=$
$\log _{10} N \frac{1}{t_{n}-t_{0}} \log \frac{N_{0}}{N_{n}}$

$3 \cdot 303$

$3 \cdot 078$

2.966

$2 \cdot 878$

$2 \cdot 734$

$2 \cdot 688$

$2 \cdot 461$

$2 \cdot 052$

$1 \cdot 384$

$-\}$

$\bar{z}\}$
-

$\cdot 107$

$\cdot 100$

$\cdot 114$

097

$\cdot 103$

.114

$\cdot 113$ $\cdot 477 \quad \cdot 137$

Mean $\overline{111}$

Exp. II, 9. 6. '09. Temperature $54 \cdot 15^{\circ} \mathrm{C}$.

\begin{tabular}{|c|c|c|c|c|c|c|c|c|}
\hline $0 \cdot 25$ & 1 & 509 & 444 & 472 & 475 & $475=N_{0}$ & $2 \cdot 677$ & - \\
\hline 0.5 & 1 & \multicolumn{3}{|c|}{$198 \quad 201$} & $199 \cdot 5$ & $199 \cdot 5$ & $2 \cdot 300$ & $1 \cdot 51$ \\
\hline 1.0 & 3 & 121 & 86 & 108 & 105 & 35 & $1 \cdot 544$ & 1.51 \\
\hline $1 \cdot 5$ & 5 & 40 & 54 & 46 & $46 \cdot 6$ & $9 \cdot 3$ & .968 & $1 \cdot 37$ \\
\hline $2 \cdot 0$ & 10 & 16 & 18 & 13 & $15 \cdot 66$ & $1 \cdot 566$ & $\cdot 195$ & $1 \cdot 42$ \\
\hline
\end{tabular}


It may therefore be said that with disinfection of B. typhosus by hot water an approximately logarithmic relation exists between time and concentration of surviving bacteria, and that any departure is in the direction of disinfection being quicker at the beginning and slower at the end of the process than would be the case if the agreement were complete.

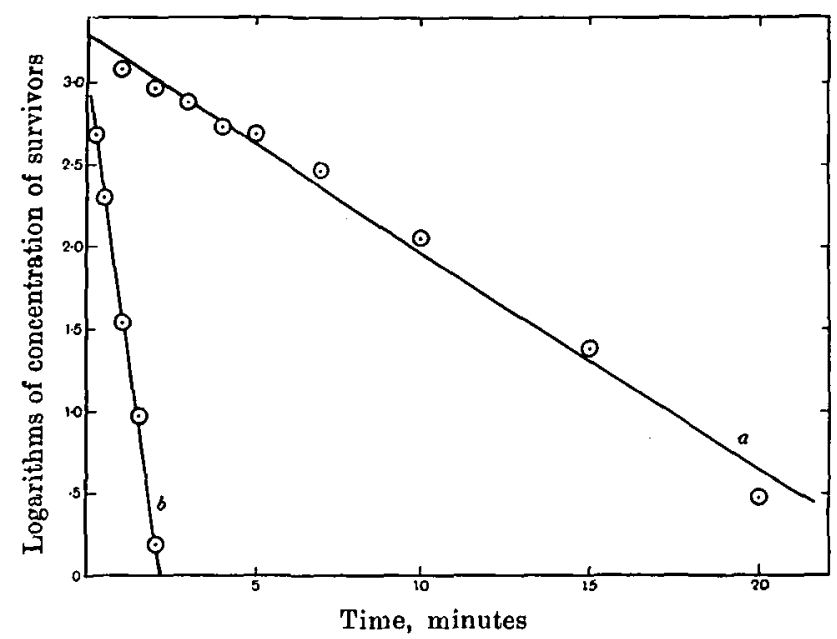

Fig. 9. Disinfection of $B$. typhosus with hot water (Table X). (a) Exp. I at $49^{\circ} \mathrm{C}$ (b) Exp. II at $54 \cdot 15^{\circ} \mathrm{C}$.

TABLE XI.

Disinfection of B. typhosus with hot water.

Exp. I, 2. 6. '09. Temperature $52^{\circ} \mathrm{C}$.

\begin{tabular}{|c|c|c|c|c|c|c|c|c|}
\hline $\begin{array}{l}\text { Time, } \\
\text { minutes } \\
=t\end{array}$ & $\begin{array}{l}\text { Amount } \\
\text { of } \\
\text { sample } \\
\text { taken, } \\
\text { drops }\end{array}$ & \multicolumn{3}{|c|}{$\begin{array}{c}\text { Numbers } \\
\text { counted } \\
\text { on plates } \\
\text { (agar) }\end{array}$} & Mean & $\begin{array}{l}\text { Mean no. of } \\
\text { bacteria present } \\
\text { in } 1 \text { drop } \\
\text { disinfection } \\
\text { mixture, }=N\end{array}$ & $\log _{10} N$ & $\begin{array}{c}K= \\
\frac{1}{t_{n}-t_{0}} \log \end{array}$ \\
\hline 0.25 & 1 & & 4 & 180 & 192 & $192=N_{0}$ & $2 \cdot 28$ & - \\
\hline 1 & 1 & 6 & 29 & 20 & $18 \cdot 3$ & $18 \cdot 3$ & $1 \cdot 26$ & $1 \cdot 36$ \\
\hline \multirow[t]{2}{*}{2} & 2 & $\mathbf{3}$ & 0 & 4 & $2 \cdot 33$ & $1 \cdot 16$ & $\cdot 06$ & $1 \cdot 27$ \\
\hline & & & & & & & \multicolumn{2}{|c|}{ Mean 1.31 } \\
\hline
\end{tabular}

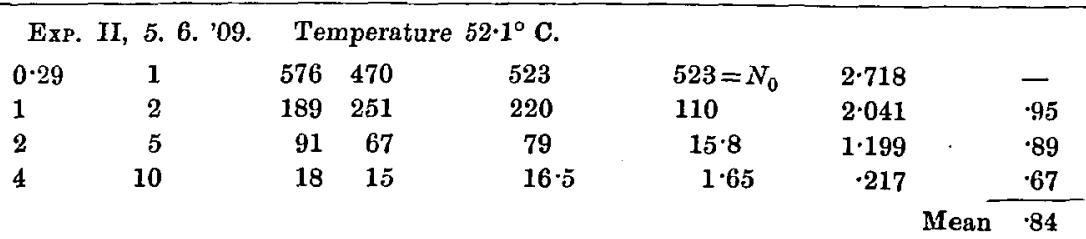


(b) B. coli commune.

Experiments made with $B$. coli commune at temperatures from $49^{\circ} \mathrm{C}$. to $53^{\circ} \mathrm{C}$. gave results similar to those with $B$. typhosus.

Table XII and Fig. 10 express the results of two experiments using agar plates; Table XIII and Fig. 11 are from experiments made with gelatine plates.

The logarithmic relation existing between concentration of survivors and time of disinfection is subject to some slight irregularity. In Exp. I, Table XII, the value of $K$ shows a general tendency to decrease,

\section{TABLE XII.}

Disinfection of $B$. coli commune with hot water.

ExP. I, 15. 2. '10. Temperature $48 \cdot 9^{\circ} \mathrm{C}$.

$\begin{array}{cc}\begin{array}{c}\text { Time, } \\ \text { minutes } \\ =t\end{array} & \begin{array}{c}\text { Amount } \\ \text { of } \\ \text { sample } \\ \text { taken, } \\ \text { drops }\end{array} \\ 0 \cdot 25=t_{0} & 1 \\ 1 \cdot 0 & 1 \\ 2 & 1 \\ 4 & \left\{\begin{array}{l}1 \\ 2\end{array}\right. \\ 6 & \left\{\begin{array}{l}1 \\ 2 \\ \end{array}\right. \\ 10 & \left\{\begin{array}{l}2 \\ 5\end{array}\right. \\ & \left\{\begin{array}{r}5 \\ 15\end{array}\right. \\ & \left\{\begin{array}{l}10 \\ 20\end{array}\right.\end{array}$

$$
\text { Numbers }
$$

counted

on plates

(agar)

$\begin{array}{lll}371 & 362 & 383\end{array}$

$266253 \quad 304$

191178201

$68 \quad 76$

129

25
44

$16 \quad 29$

67

$15 \quad 18$

16
Mean no. of bacteria present

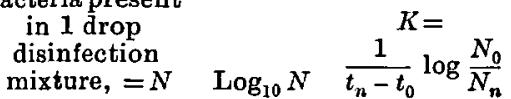

Mean

372

$274 \cdot 3$

190

$-1$

$-\}$

- ?

$-1$

-

$-$
-

$\cdot 176$

$\cdot 166$

$\begin{array}{lll}68 \cdot 25 & 1 \cdot 834 \quad \cdot 196\end{array}$

$23 \quad 1 \cdot 362 \quad \cdot 210$

$12 \cdot 4 \quad 1 \cdot 093 \quad \cdot 152$

$1 \cdot 72 \quad \cdot 235 \quad \cdot 159$

$\cdot 425 \quad-\cdot 372 \quad \cdot 149$

Mean $\overline{\cdot 172}$

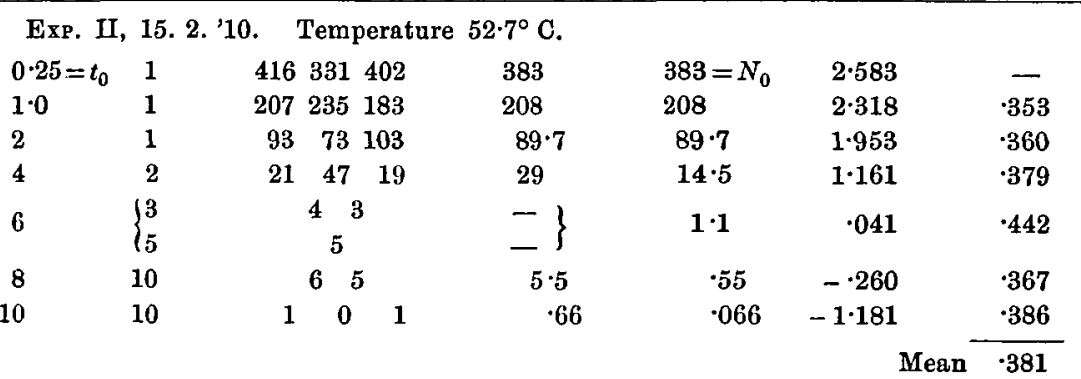




\section{TABLE XIII.}

Disinfection of $B$. coli commune with hot water.

Exp. I, 26. 2. '10. Temperature $49^{\circ} \mathrm{C}$.

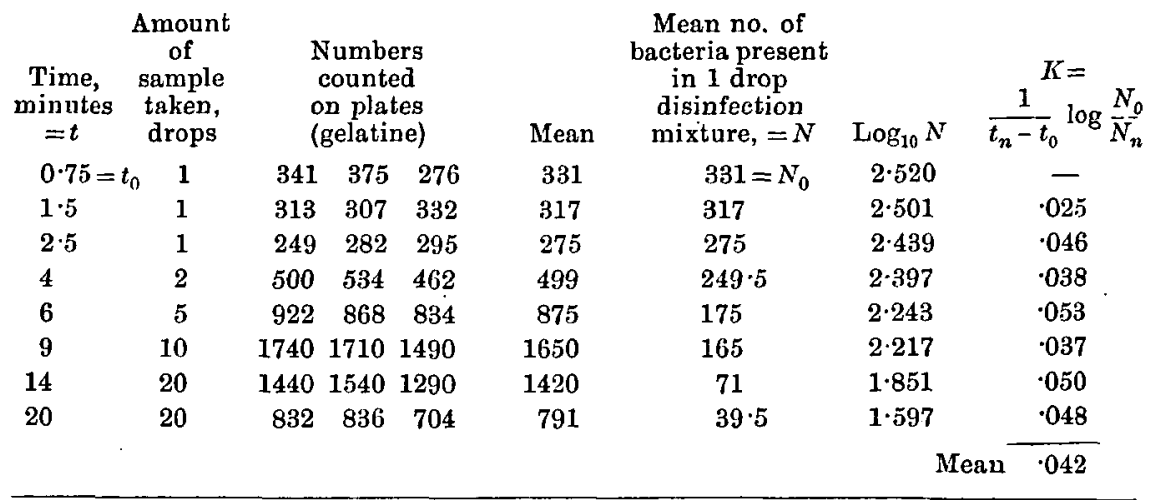

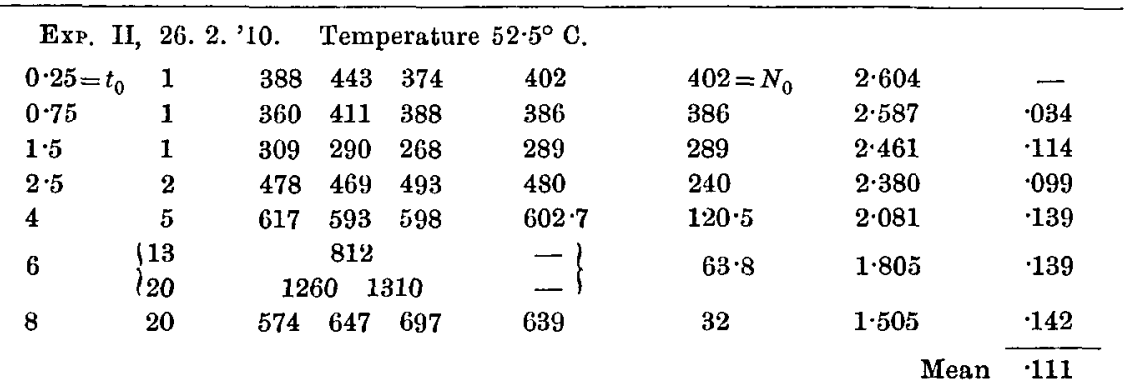

in Exp. II and in both experiments in Table XIII to increase as disinfection proceeds. The latter type bears a resemblance to the experiments of Eijkman (see above, p. 249). All, however, conform more nearly than his to what I may call the ideal case, and, considering that the deviation is small, and not consistently in one direction, and that the species is moreover extremely variable, I conclude that here also disinfection proceeds so that the rate is approximately proportional to the concentration of survivors, and that straight lines most satisfactorily express the relation between the experimental points when logarithms of the latter are plotted against time.

The variability of this species is well shown by a comparison of Tables XII and XIII, where rate of disinfection of apparently similar material, at approximately the same temperature, is in the one case about four times as great as in the other. 
H. ChroK

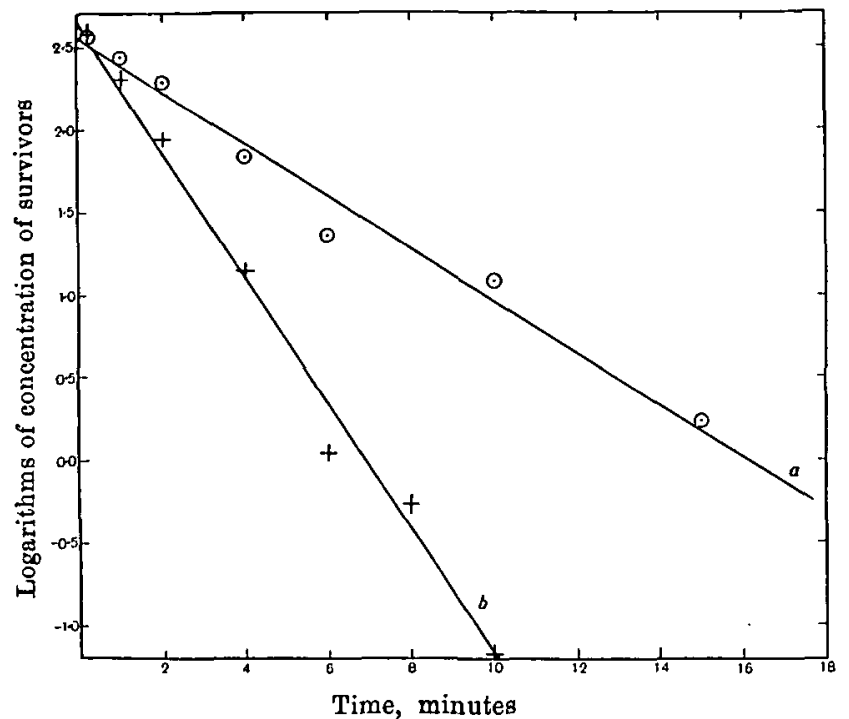

Fig. 10. Disinfection of $B$. coli commune with hot water (Table XII). (a) Exp. I at $48 \cdot 9^{\circ} \mathrm{C}$. (b) Exp. II at $52 \cdot 7^{\circ} \mathrm{C}$.

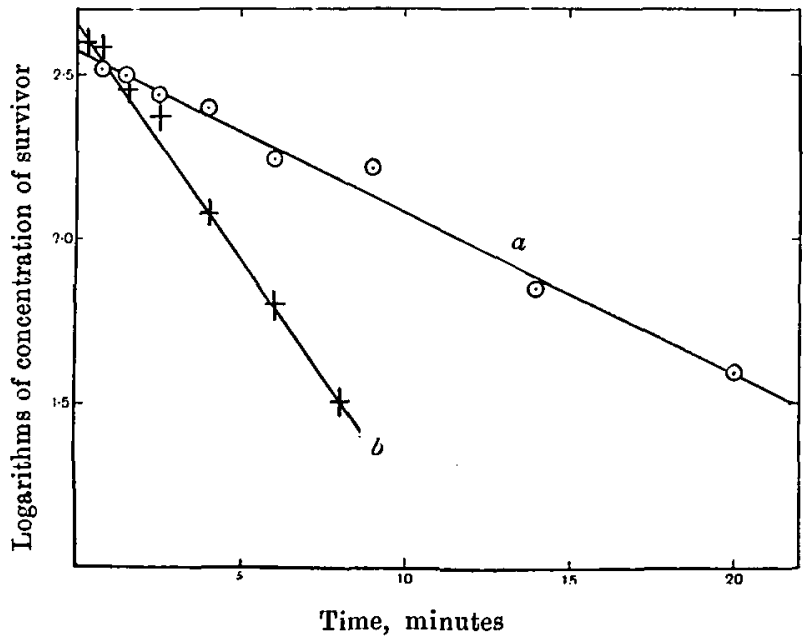

Fig. 11. Disinfection of $B$. coli commune with hot water (Table XIII).
(a) Exp. I at $49^{\circ} \mathrm{C}$.
(b) Exp. II at $52 \cdot 5^{\circ} \mathrm{C}$. 


\section{(c) Experiments with B. paralyphosus.}

Experiments were made with 24 hours' cultures of $B$. paratyphosus at a temperature of $47 \cdot 2-47 \cdot 3^{\circ} \mathrm{C}$, at which temperature the rate of death is fairly rapid. 'I'he results of three experiments are given in Table XIV and Fig. 12.

\section{TABLE XIV.}

Disinfection of B. paratyphosus with hot water.

Exp. I, 5. 5. '09. Temperature $47 \cdot 2^{\circ} \mathrm{C}$.

$\begin{array}{cc}\begin{array}{c}\text { Amount } \\ \text { of } \\ \text { Time, } \\ \text { samples } \\ =t\end{array} & \begin{array}{c}\text { taken, } \\ \text { drops }\end{array} \\ 1 \cdot 05 & 1 \\ 2 \cdot 2 & 1 \\ 3=t_{0} & 1 \\ 5 & 1 \\ 7 & 2 \\ 10 & 3 \\ 15 & 5 \\ 20 & 5 \\ & 5\end{array}$

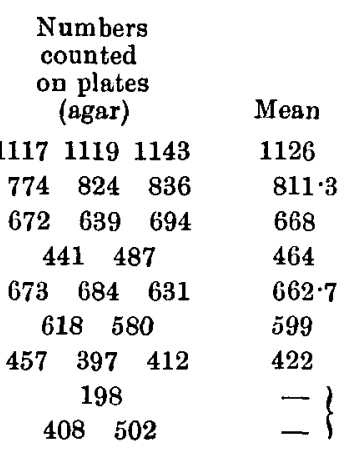

\begin{tabular}{ccc}
$\begin{array}{c}\text { Mean no. of } \\
\text { bacteria present } \\
\text { in 1 drop } \\
\text { disinfection } \\
\text { mixture, }=N\end{array}$ & \multicolumn{2}{c}{$K=$} \\
1126 & $\log _{10} N$ & $\frac{1}{t_{n}-t_{0}} \log \frac{N_{0}}{N_{n}}$ \\
811.3 & 2.051 & - \\
$668=N_{0}$ & 2.809 & - \\
464 & $2 \cdot 666$ & -079 \\
331.3 & 2.520 & .076 \\
199.7 & $2 \cdot 300$ & .075 \\
84.4 & 1.926 & .075 \\
44.3 & 1.646 & .069 \\
& \multicolumn{2}{c}{ Mean -.075}
\end{tabular}

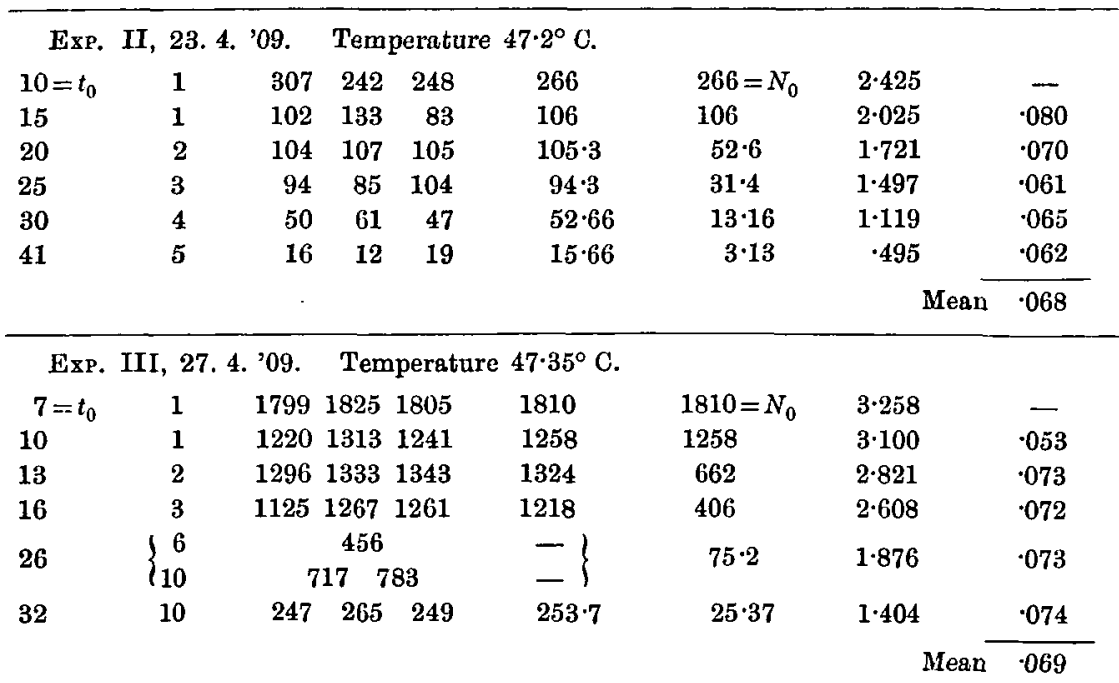


After the first few minutes the accordance with the logarithmic law is very good, but, as was found to be the case with chemical disinfectants, the reaction proceeds more rapidly at first than would be the case were the rate dependent only upon the concentration of surviving bacteria.

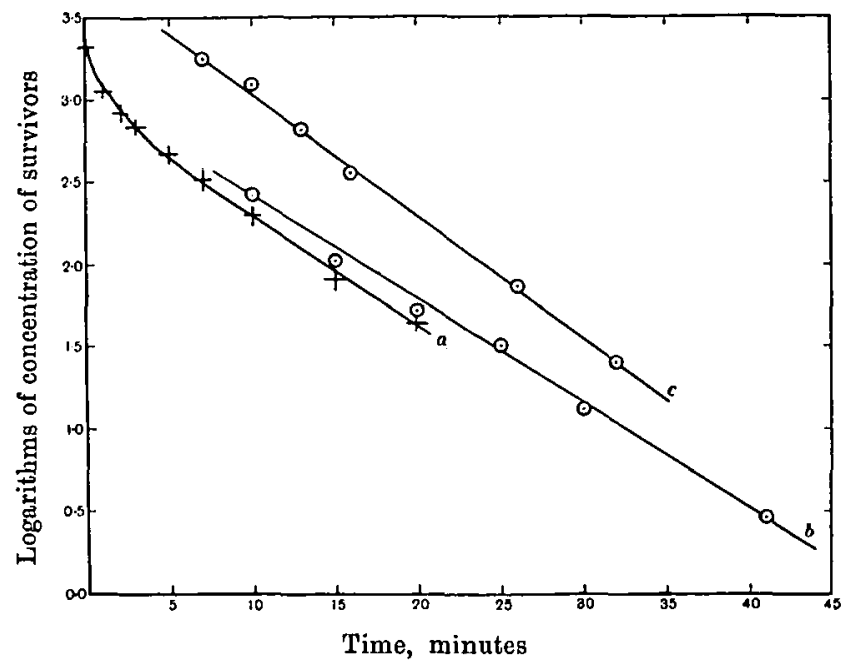

Fig. 12. Disinfection of $B$. paratyphosus with hot water (Table XIV).
(a) Exp. I at $47 \cdot 2^{\circ} \mathrm{C}$.
(b) Exp. II at $47 \cdot 2^{\circ} \mathrm{C}$.
(c) Exp. III at $47 \cdot 35^{\circ} \mathrm{C}$.

(d) Staphylococcus pyogenes albus and Staphylococcus pyogenes aureus.

Staphylococcus pyogenes albus. The results of two experiments with Staphylococcus albus at $49^{\circ} \mathrm{C}$. and $53.05^{\circ} \mathrm{C}$. respectively are given in Table XV and Fig. 13; they show fair agreement with the logarithmic law.

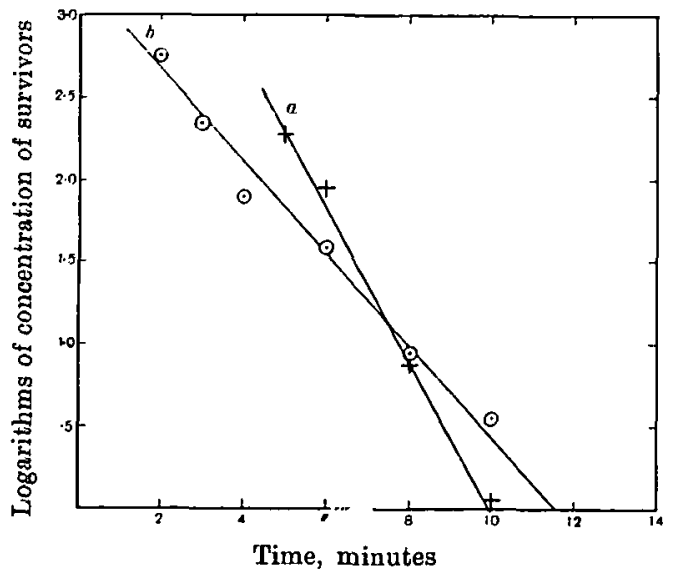

Fig. 13. Disinfection of Staphylococcus pyogenes albus with hot wator (Table XV).
(a) Exp. I at $53 \cdot 05^{\circ} \mathrm{C}$.
(b) Exp. II. at $49^{\circ} \mathrm{C}$. 
From analogy with other species one would expect the rate of disinfection at $53^{\circ} \mathrm{C}$. (Exp. I) to be greatly in excess of that at $49^{\circ} \mathrm{C}$. (Exp. II). The experiments were not made at the same time, and it must be concluded that this form, like Staphylococcus pyogenes aureus, is very variable as regards its resistance to disinfection by hot water.

TABLE XV.

Disinfection of Staphylococcus pyogenes albus with hot water.

Exp. I, 10. 3. '09. Temperature $53 \cdot 05^{\circ} \mathrm{C}$.

\begin{tabular}{|c|c|c|c|c|c|c|c|c|}
\hline $\begin{array}{l}\text { Time, } \\
\text { minutes } \\
=t\end{array}$ & $\begin{array}{l}\text { Amount } \\
\text { of } \\
\text { sample } \\
\text { taken, } \\
\text { drops }\end{array}$ & \multicolumn{3}{|c|}{$\begin{array}{c}\text { Numbers } \\
\text { counted } \\
\text { on plates } \\
\text { (agar) }\end{array}$} & \multirow{2}{*}{$\begin{array}{c}\text { Mean } \\
380\end{array}$} & \multirow[t]{2}{*}{$\begin{array}{l}\text { Mean no. of } \\
\text { bacteria present } \\
\text { in 1 drop } \\
\text { disinfeetion } \\
\text { mixture, }=N \\
\quad 190=N_{0}\end{array}$} & \multirow{2}{*}{$\begin{array}{c}\log _{10} N \\
2 \cdot 279\end{array}$} & \multirow{2}{*}{$\begin{array}{c}K= \\
\frac{1}{t_{n}-t_{0}} \log \frac{N_{0}}{N_{n}}\end{array}$} \\
\hline $5=t_{0}$ & 2 & 371 & 393 & 376 & & & & \\
\hline 6 & 5 & 386 & 501 & 459 & 449 & $89 \cdot 8$ & $1 \cdot 953$ & $\cdot 33$ \\
\hline 8 & 10 & & 608 & & 74 & $7 \cdot 4$ & .869 & $\cdot 47$ \\
\hline \multirow[t]{2}{*}{10} & 10 & & $\begin{array}{ll}9 & 1\end{array}$ & & $11 \cdot 5$ & $1 \cdot 15$ & .061 & $\cdot 44$ \\
\hline & & & & & & & \multicolumn{2}{|c|}{ Mean $\cdot 41$} \\
\hline
\end{tabular}

Exp. II, 12. 3. '09. Temperature $49^{\circ} \mathrm{C}$.

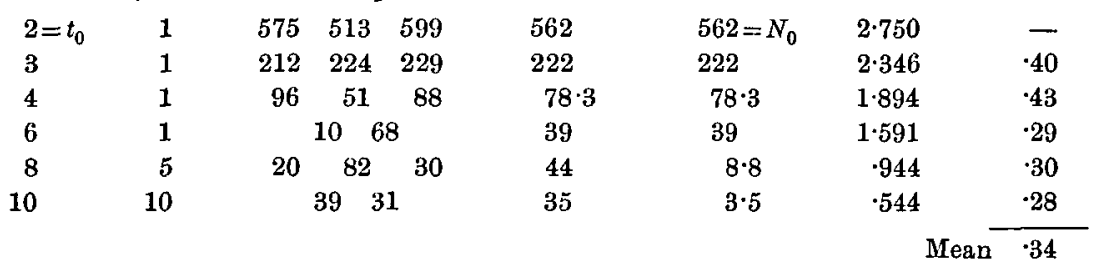

\section{TABLE XVI.}

Disinfection of Staphylococcus pyogenes aureus with hot water at $49 \cdot 3^{\circ} \mathrm{C}$.

Exp. 21. 5. '09. (24 hours' culture from stock culture 44 days old.)

\begin{tabular}{|c|c|c|c|c|c|c|}
\hline $\begin{array}{l}\text { Time, } \\
\text { minutes } \\
=t\end{array}$ & $\begin{array}{l}\text { Amount } \\
\text { of } \\
\text { sample } \\
\text { taken, } \\
\text { drops }\end{array}$ & $\begin{array}{c}\text { Numbers } \\
\text { counted } \\
\text { on plates } \\
\text { (agar) }\end{array}$ & Mean & $\begin{array}{l}\text { Mean no. of } \\
\text { bacteria present } \\
\text { in } 1 \text { drop } \\
\text { disinfection } \\
\text { mixture, }=N\end{array}$ & $\log _{10} N$ & ${\frac{1}{t_{n}-t_{0}}}^{K=} \log \frac{N}{N}$ \\
\hline $1=t_{0}$ & 1 & $1826 \quad 1904$ & 1865 & $1865=N_{0}$ & $3 \cdot 271$ & - \\
\hline 2 & 1 & 1457 & 1457 & 1457 & $3 \cdot 163$ & $\cdot 108$ \\
\hline 3 & 1 & $929 \quad 1279$ & 1104 & 1104 & $3 \cdot 043$ & $\cdot 114$ \\
\hline 7 & 1 & 517 & 517 & 517 & $2 \cdot 713$ & .093 \\
\hline 10 & 1 & $416 \quad 443$ & 429 & 429 & $2 \cdot 632$ & .071 \\
\hline 15 & 2 & 283 & 283 & $141 \cdot 5$ & $2 \cdot 149$ & $\cdot 080$ \\
\hline
\end{tabular}




\section{H. ChICK}

Staphylococcus pyogenes aureus. On examination of the results of experiments with Staphylococcus pyogenes aureus (Tables XVI to XIX and Figs. 14 to 17), it is seen that in this case disinfection by hot water conforms to no constant type. In almost all cases the latter part of the disinfection proceeds logarithmically (see Exps. I and II, Table XIX, and Fig. 17, which are concerned with the course of disinfection after 10 minutes and 16 minutes respectively have elapsed), but the time relations of the disinfection process as a whole present great variety among which three distinct types can be distinguished:

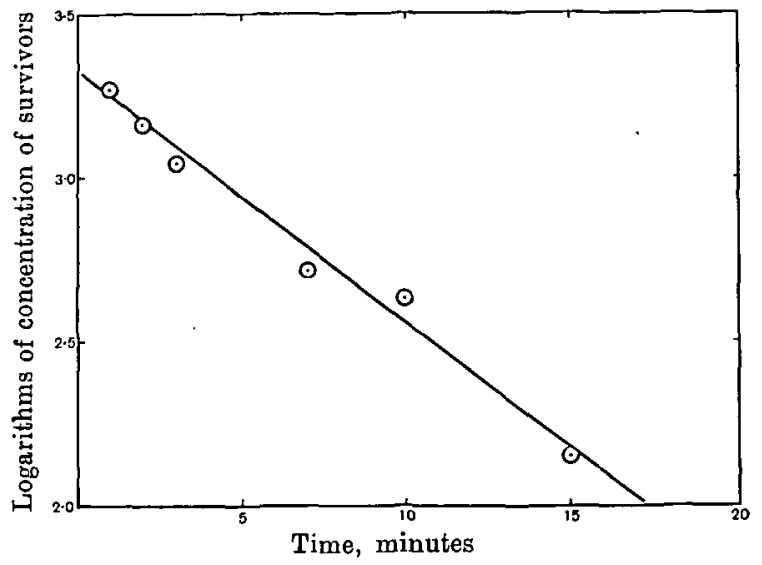

Fig. 14. Disinfection of Staphylococcus pyogenes aureus with hot water at $49 \cdot 3^{\circ} \mathrm{C}$. (Table XVI).

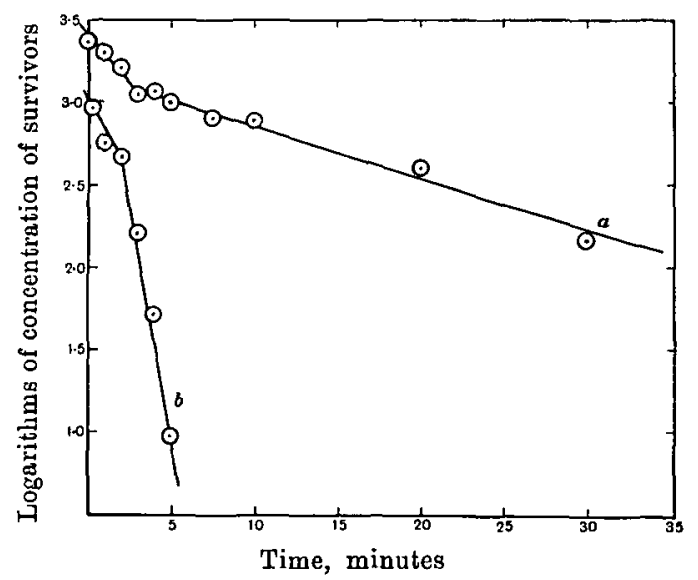

Fig. 15. Disinfection of Staphylococcus pyogenes aureus with hot water (Table XVII). (a) Exp. I at $49 \cdot 3^{\circ} \mathrm{C}$.

(b) Exp. II at $49^{\circ} \mathrm{C}$. 


\section{TABLE XVII.}

Disinfection of Staphylococcus pyogenes aureus with hot water.

Exp. I, 13. 5. '09. (24 hours' culture from stock culture 36 days old.) Temp. $49 \cdot 3^{\circ} \mathrm{C}$.

\begin{tabular}{|c|c|c|c|c|c|c|}
\hline $\begin{array}{l}\text { Time, } \\
\text { minutes } \\
=t\end{array}$ & $\begin{array}{l}\text { Amount } \\
\text { of } \\
\text { sample } \\
\text { taken, } \\
\text { drops }\end{array}$ & $\begin{array}{l}\text { Numbers } \\
\text { counted } \\
\text { on plates } \\
\text { (agar) }\end{array}$ & Mean & $\begin{array}{l}\text { Mean no. of } \\
\text { bacteria present } \\
\text { in } 1 \text { drop } \\
\text { disinfection } \\
\text { mixture, }=N\end{array}$ & $\log _{10} N$ & $\begin{array}{c}K= \\
\frac{1}{t_{n}-t_{0}} \log \frac{N_{0}}{N_{n}}\end{array}$ \\
\hline $1=t_{0}$ & 1 & $21682522 \quad 2024$ & 2238 & $2238=N_{0}$ & $3 \cdot 350$ & 一 \\
\hline 2 & 1. & $1698 \quad 1649 \quad 1516$ & 1621 & 1621 & $3 \cdot 210$ & $\cdot 140$ \\
\hline 3 & 1 & 110511821119 & 1135 & 1135 & 3.055 & $\cdot 147$ \\
\hline 4 & 1 & $1068 \quad 1343 \quad 1125$ & 1179 & 1179 & $3 \cdot 072$ & $\cdot 093$ \\
\hline 5 & 1 & $\begin{array}{lll}971 & 1023 & 1082\end{array}$ & 1025 & 1025 & $3 \cdot 011$ & .085 \\
\hline 7 & 1 & 819 & 819 & 819 & $2 \cdot 913$ & $\cdot 073$ \\
\hline 10 & 2 & $\begin{array}{lll}1372 & 1558 & 1619\end{array}$ & 1516 & 758 & $2 \cdot 880$ & .052 \\
\hline 20 & 3 & $1320 \quad 1160$ & 1240 & 413 & $2 \cdot 616$ & $\cdot 039$ \\
\hline 30 & $\left\{\begin{array}{r}7 \\
10\end{array}\right.$ & $\begin{array}{l}1101 \\
1388\end{array}$ & $-\}$ & 146 & $2 \cdot 164$ & $\cdot 041$ \\
\hline
\end{tabular}

Exp. II, 3. 6. '09. (24 hours' culture from stock culture 13 days old.) Temp. $49^{\circ} \mathrm{C}$.

\begin{tabular}{|c|c|c|c|c|c|c|}
\hline $0 \cdot 25=t_{0}$ & 1 & 912 & 912 & $912=N_{0}$ & $2 \cdot 960$ & - \\
\hline $1 \cdot 0$ & 1 & $525 \quad 570$ & 547 & 547 & $2 \cdot 738$ & $\cdot 30$ \\
\hline 2 & 1 & $542 \quad 393$ & 467 & 467 & $2 \cdot 669$ & $\cdot 17$ \\
\hline 3 & 1 & $224 \quad 108$ & 166 & 166 & $2 \cdot 220$ & $\cdot 27$ \\
\hline 4 & 1 & $42 \quad 60$ & 51 & 51 & $1 \cdot 708$ & $\cdot 33$ \\
\hline 5 & 2 & $\begin{array}{lll}22 & 14 & 20\end{array}$ & $18 \cdot 66$ & $9 \cdot 33$ & $\cdot 970$ & $\cdot 42$ \\
\hline & & & & & Mean & $\cdot 30$ \\
\hline
\end{tabular}

(1) Disinfection rate is throughout approximately proportional to the concentration of survivors (Table XVI), and a straight line best expresses the relation of the points when logarithms of survivors are plotted against time (Fig. 14).

(2) There is a "period of lag" at the beginning of disinfection (see Exp. II, Table XVII, and Exps. I, II and III, Table XVIII, where the value of $K$ progressively increases) recalling disinfection of this species with phenol; a convex curve is obtained when logarithms of concentration of survivors are plotted against time (Fig. $15 b$ and Fig. 16).

(3) Disinfection is much accelerated at the beginning and becomes slower afterwards (see Exp. I, Table XVII, where the value of $K$ progressively decreases); a concave curve is obtained when logarithms of concentration of survivors are plotted against time (see Fig. 15 a). 


\section{TABLE XVIII.}

Disinfection of Stuphylococcus pyogenes aureus by hot water.

(24 hours' culture from very young stock cultures.)

Exp. I, 24. 1. '10. (24 hours' culture from stock culture 5 days old.) Temp, 48.9 ${ }^{\circ}$.

\begin{tabular}{|c|c|c|c|c|c|c|}
\hline $\begin{array}{l}\text { Tinue, } \\
\text { minutes } \\
=t\end{array}$ & $\begin{array}{l}\text { Amount } \\
\text { of } \\
\text { sample } \\
\text { taken, } \\
\text { drops }\end{array}$ & $\begin{array}{l}\text { Numbers } \\
\text { counted } \\
\text { on plates } \\
\text { (gelatine) }\end{array}$ & Mean & $\begin{array}{l}\text { Mean no. of } \\
\text { bacteria present } \\
\text { in } 1 \text { drop } \\
\text { disinfection } \\
\text { mixture, }=N\end{array}$ & $\log _{10} N$ & $\begin{array}{c}K= \\
\frac{1}{t_{n}-t_{0}} \log \frac{N}{N}\end{array}$ \\
\hline $0 \cdot 25=t_{0}$ & 1 & $\begin{array}{lll}1800 & 1790 & 1090\end{array}$ & 1560 & $1560=N_{0}$ & $3 \cdot 193$ & 一 \\
\hline $2 \cdot 0$ & 1 & 12301330 & 1280 & 1280 & $3 \cdot 107$ & $=(0491$ \\
\hline 5 & 2 & $\begin{array}{lll}1890 & 1930 & 2010\end{array}$ & 1940 & 970 & $2 \cdot 987$ & 票 $\{.0434$ \\
\hline 10 & 2 & $980 \quad 910$ & 945 & $472 \cdot 5$ & $2 \cdot 674$ & ? .0532 \\
\hline 20 & $\left\{\begin{array}{r}7 \\
10\end{array}\right.$ & $\begin{array}{l}29 \\
52\end{array}$ & $-\}$ & $4 \cdot 8$ & $\cdot 681$ & $\cdot 127$ \\
\hline
\end{tabular}

Exp. II, 24. 1. '10. (24 hours' culture from stock culture 6 days old.) Temp. 52.9० C.

\begin{tabular}{|c|c|c|c|c|c|c|c|}
\hline $0 \cdot 25=t_{0}$ & 1 & $\begin{array}{lll}1230 & 1110 & 1180\end{array}$ & 1170 & $1170=N_{0}$ & $3 \cdot 068$ & & - \\
\hline $1 \cdot 0$ & 1 & $\begin{array}{lll}990 & 840 & 810\end{array}$ & 880 & 880 & $2 \cdot 944$ & & $\cdot 165$ \\
\hline 2 & 2 & $1020 \quad 1270$ & 1145 & 572 & $2 \cdot 757$ & 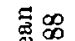 & $\cdot 176$ \\
\hline 5 & $\left\{\begin{array}{r}6 \\
10\end{array}\right.$ & $\begin{array}{c}590 \\
1130^{940}\end{array}$ & $-\}$ & 102 & $2 \cdot 009$ & $\stackrel{\sim}{*}$ & $\cdot 223$ \\
\hline & 10 & 0 & $2 \cdot \mathbf{3}$ & 0.23 & $-\cdot 638$ & & $\cdot 380$ \\
\hline
\end{tabular}

ExP. III, 9. 2. '10. (24 hours' culture from stock culture 2 days old.) Temp. $52 \cdot 6^{\circ} \mathrm{C}$.

\begin{tabular}{|c|c|c|c|c|c|c|c|c|}
\hline 0.25 & 1 & \multicolumn{2}{|r|}{ Lost } & & & & & \\
\hline $1 \cdot 0=t_{0}$ & 1 & & $7 \quad 594$ & $555 \cdot 5$ & $555 \cdot 5=N_{0}$ & $2 \cdot 745$ & & - \\
\hline 2 & 1 & \multicolumn{2}{|r|}{353} & 353 & 353 & $2 \cdot 548$ & & $\cdot 197$ \\
\hline 4 & 2 & \multicolumn{2}{|c|}{$264 \quad 195$} & $229 \cdot 5$ & $114 \cdot 7$ & $2 \cdot 060$ & 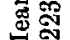 & .228 \\
\hline 6 & 5 & 182 & $151 \quad 176$ & $169 \cdot 7$ & $33 \cdot 9$ & $1 \cdot 530$ & & .243 \\
\hline 8 & $\left\{\begin{array}{r}8 \\
10\end{array}\right.$ & \multicolumn{2}{|r|}{$\begin{array}{l}29 \\
26\end{array}$} & $-\}$ & $3 \cdot 1$ & $\cdot 491$ & & $\cdot 322$ \\
\hline & 20 & \multicolumn{2}{|r|}{4} & 4 & 0.2 & $-\cdot 699$ & & $\cdot 344$ \\
\hline
\end{tabular}

The reason ${ }^{1}$ for this irregularity was not discovered, it is possible that the cause lies in the variability of the species and may depend upon the special character of the stock culture from which the 24 bours' culture was prepared. It was generally true that disinfection of cultures

1 The suggestion is made that in some cases these irregularities are only apparent, and may be due to agglutinations, taking place at once (type 3), or after an interval of time (type 2), when an emulsion of the bacteria is suspended in hot water. Cultures of Staphylococcus readily agglutinate when suspensions in water or broth are heated to temperatures somewhat higher than those employed in the present experiments. Attempts were therefore made to trace microscopically any agglutination that might occur, but nothing significant could be detected. It is however certain that an agglutination which would apparently increase the rate of disinfection three or four times (see Tables XVII and XVIII) would be very insignificant and almost impossible to detect with the microscope.

Journ. of Hyg, $x$ 
made from fresh stock cultures (under a week old) was of the 2nd type, while that of material obtained from older stock cultures conformed to the 1st or 3rd type.

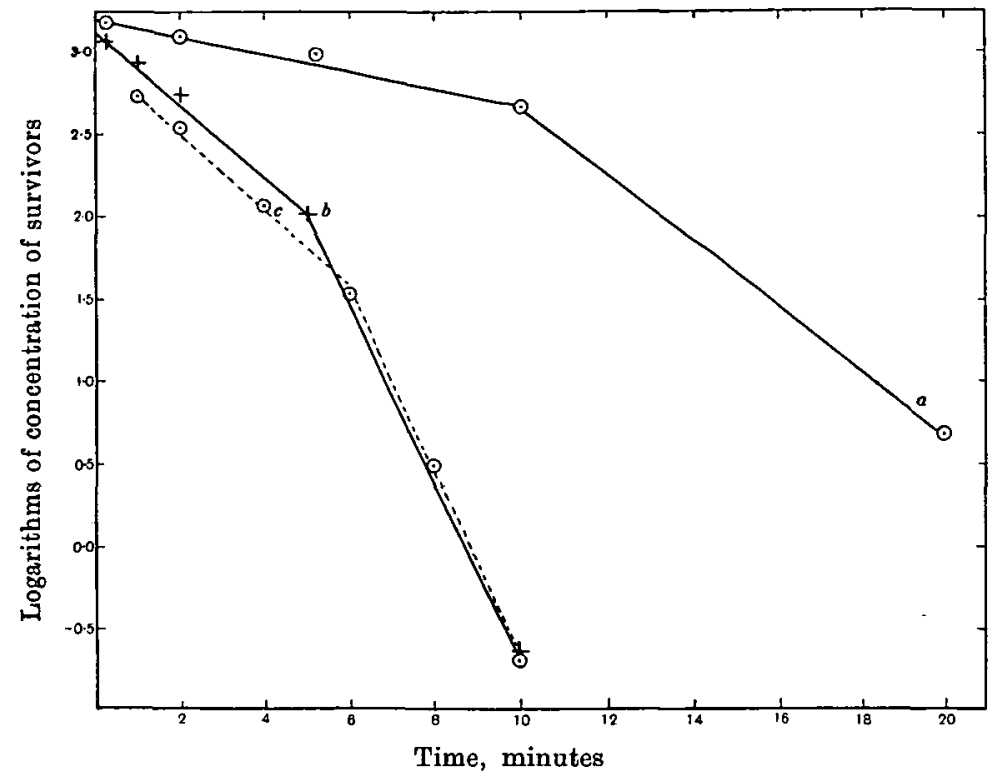

Fig. 16. Disinfection of Staphylococcus pyogenes aureus with hot water (Table XVIII). (a) Exp. I at $48 \cdot 9^{\circ} \mathrm{C} .(\odot)$. (b) Exp. II at $52 \cdot 9^{\circ} \mathrm{C} .(+)$. (c) Exp. III at $52 \cdot 6^{\circ} \mathrm{C} .(\odot)$.

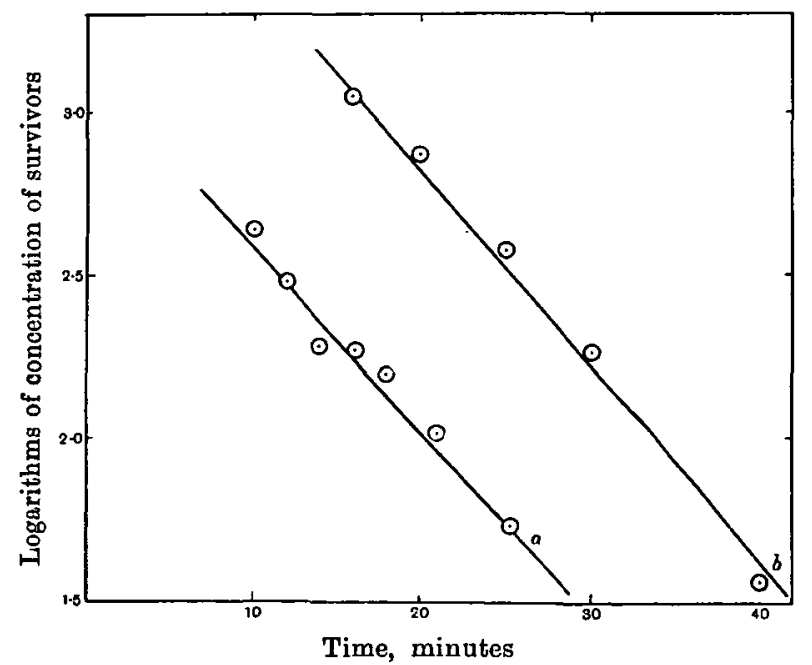

Fig. 17. Disinfection of Staphylococcus pyogenes aureus by hot water at $49 \cdot 3^{\circ} \mathrm{C}$. (Table XIX).
(a) Exp. I.
(b) Exp. II. 
TABLE XIX.

Disinfection of Staphylococcus pyogenes aureus with hot water at $49 \cdot 3^{\circ} \mathrm{C}$.

Exp. I, 8. 4. '09. (24 hours' culture from stock culture 11 days old.)

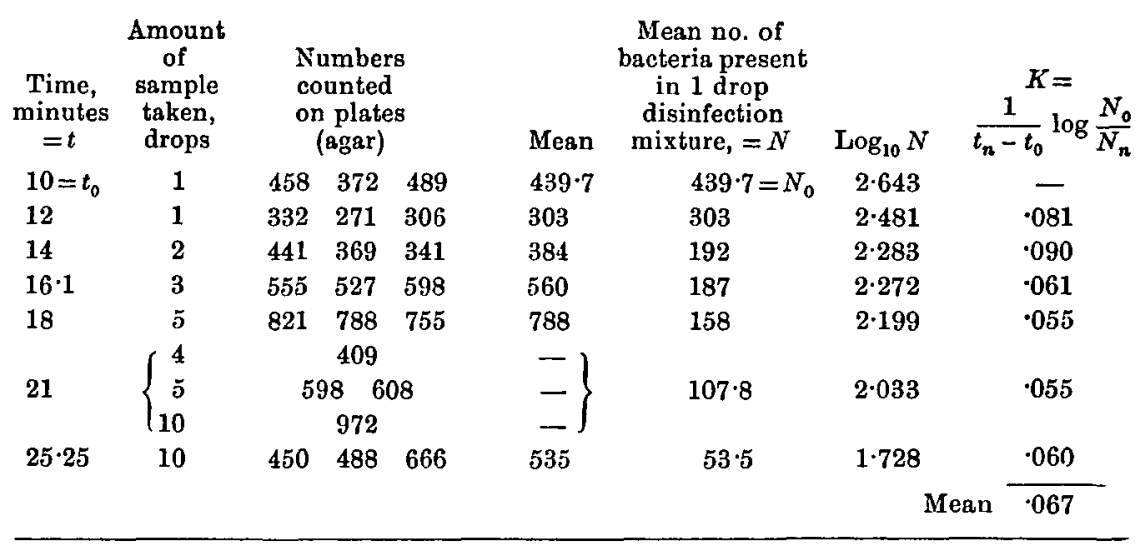

Exp. II, 14. 4. '09. (24 hours' culture from stock culture 7 days old.)

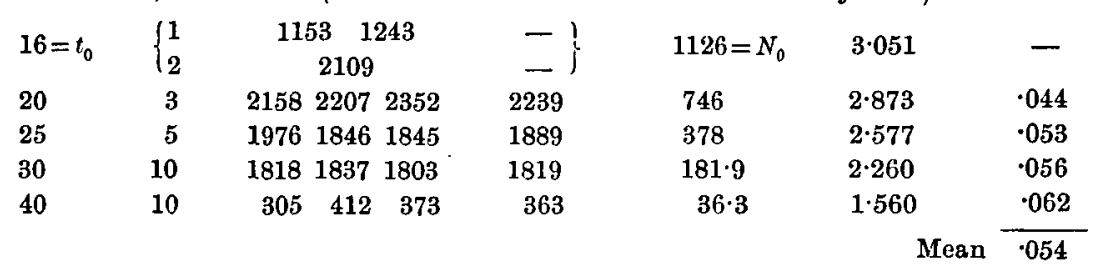

Besides a general want of consistency in the character of the disinfection process itself, the average velocity of disinfection under apparently similar conditions is also extremely variable. Great difficulty in obtaining constancy of resistance in cultures would appear to be characteristic of work with Staphylococcus. In disinfection by hot water it was unusual to obtain the same result twice, unlookedfor alterations in resistance were constantly occurring, for which the responsibility was not satisfactorily traced. For example, Table XVII, Experiment II, shows a value of the velocity constant which is nearly three times that of the average in Experiment I, and four to five times that in Experiments I and II, Table XIX, all of which were made under almost identical conditions as regards temperature.

There is no entirely satisfactory explanation for these inconsistencies. As mentioned above, I find that the previous history of cultures of Staphylococcus modifies very considerably their behaviour towards 
disinfectants; in the case of disinfection with phenol, difference in temperature of incubation had an unexpectedly great influence upon the resistance of the bacteria towards phenol (see above, p. 247). It is probable that it also modifies its resistance to hot water.

\section{(e) B. pestis.}

The results of one experiment with B. pestis at $50^{\circ} \mathrm{C}$. (Table $\mathrm{XX}$ and Fig. 18) show fair agreement with the logaritbmic law.

\section{TABLE XX.}

Disinfection of $B$. pestis with hot water at $50^{\circ} \mathrm{C}$.

$\begin{array}{cccc}\text { Time, minutes } \\ =t & \begin{array}{c}\text { No. of organisms } \\ \text { in } 5 \text { drops disinfec. } \\ \text { tion mixture, }=N\end{array} & \log _{10} N & \frac{1}{t_{n}-t_{0}} \log \frac{N_{0}}{N_{n}} \\ 4 \cdot 25=t_{0} & 9440=N_{0} & 3 \cdot 975 & - \\ 7 \cdot 0 & 6880 & 3 \cdot 838 & \cdot 050 \\ 9 \cdot 75 & 6160 & 3 \cdot 790 & \cdot 034 \\ 13 \cdot 0 & 4460 & 3 \cdot 649 & \cdot 037 \\ 16 \cdot 0 & 3340 & 3 \cdot 524 & .038 \\ & & & \text { Mean } \cdot \cdot 040\end{array}$

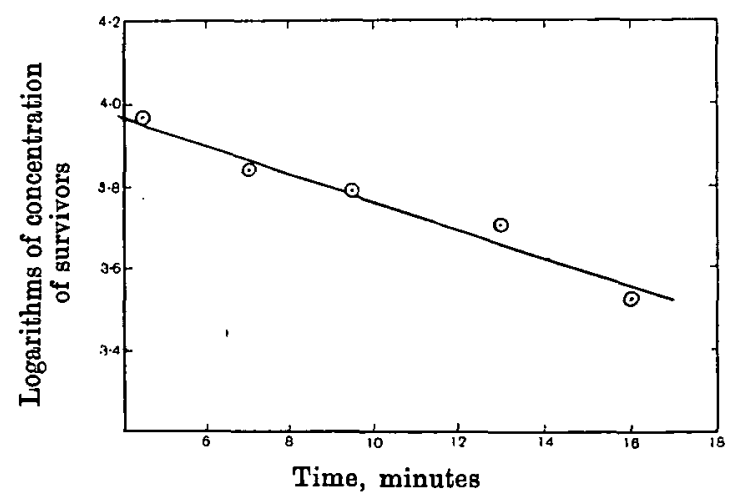

Fig. 18. Disinfection of $B$. pestis with hot water at $50^{\circ} \mathrm{C}$. (Table XX).

(3) Temperature coefficient of disinfection by hot water.

$B$. typhosus. The experiments with $B$. typhosus extended over a range of $5^{\circ} \mathrm{C}$., and the temperature coefficient of disinfection by hot water could therefore be determined with some accuracy by comparing 
velocity constants of two comparable disinfections at different temperatures. In Experiments I and II, Table $X$, the mean value of the velocity constant at $54 \cdot 1^{\circ} \mathrm{C}$. was $1 \cdot 45$, while that corresponding to $49^{\circ} \mathrm{C}$. was 0.111 .: This gives an increase in reaction velocity of 13.1 times for $5^{\circ} \mathrm{C}$. rise in temperature, i.e. 1.67 times per $1^{\circ} \mathrm{C}$., and about 170 times per $10^{\circ} \mathrm{C}$. rise in temperature, if the temperature effect is assumed to be consistent.

To ascertain the truth or otherwise of this assumption and for purposes of comparison, some additional experiments were made with $B$. typhosus, using an end-point method (see H. C. 1908, p. 118). Test tubes containing 5 c.c. of distilled water and fitted with standardised capillary pipettes were placed in thermostats maintained at different temperatures and sown with a small quantity ( 5 standard drops $=0 \cdot 1$ c.c.) from a 24 hours' culture of B. typhosus. From time to time samples ( 4 drops $=0.08$ c.c.) were withdrawn by means of the capillary pipette and added to tubes of glucose broth, which were then incubated. The time necessary for complete disinfection was taken as the mean between that of the last positive and first negative test culture. These times of "complete disinfection" strictly mean the time taken for an initial concentration of about 5,000,000 bacteria per c.c. to be reduced to less than 12 per c.c., i.e. till there may not be one living bacteria present in the sample taken, 0.08 c.c.

The results of two experiments (Table XXI) are consistent one with the other. A logarithmic relation was found to express the effect of temperature upon disinfection velocity, as was expected from analogy with other cases of disinfection which have been investigated. Logarithms of times taken for disinfection (reciprocals of mean reaction velocity) were found to be proportional to the differences of temperature, and, when plotted one against the other, gave approximately a straight line, see Fig. 19.

Whether rise of temperature affects the velocity of disinfection by hot water in a simple logarithmic manner or in accordance with the Law of Arrhenius, it is impossible to say, for within a small range of temperature the two become almost identical. The somewhat rough experimental method could not be expected to give very strict mathematical agreement with either, though as a matter of fact satisfactory agreement with both is obtained (see also temperature coefficient of disinfection with disinfectants, H. C. 1908, p. 153).

In any case the effect of temperature upon disinfection with hot water is seen to be consistent and very great. From Table XXI the mean 
value 1.60 is obtained as temperature coefficient per $1^{\circ} \mathrm{C}$. From the slope of the smoothed curve in Fig. $19 \mathrm{it}$, is seen that a rise of $10^{\circ} \mathrm{C}$. in temperature from $49^{\circ} \mathrm{C}$. to $59^{\circ} \mathrm{C}$. indicates an increase of 2.00 in the logarithms of the times taken, i.e. an increase in the mean velocity of disinfection of 100 times, or 1.58 times for $1^{\circ} \mathrm{C}$. These values are in fair agreement with that obtained by comparing velocity constants, viz. 167 per $1^{\circ} \mathrm{C}$.

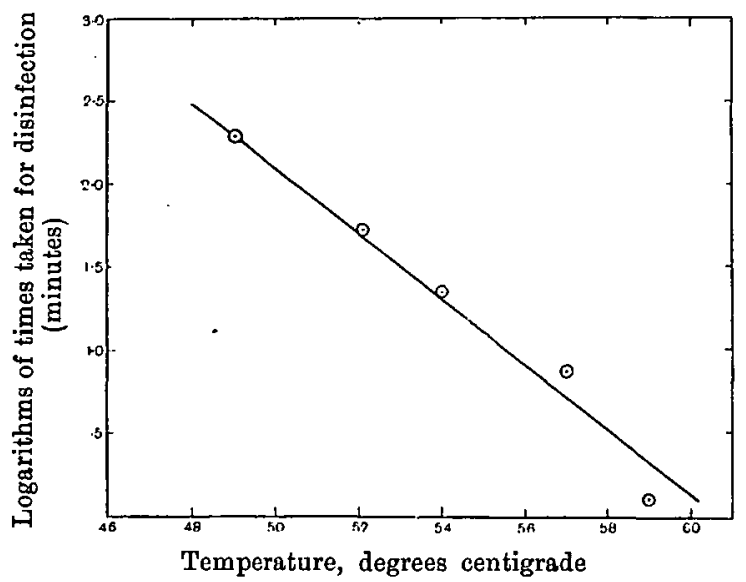

Fig. 19. Effect of different temperatures upon disinfection of $B$. typhosus by hot water (Table XXI).

TABLE XXI.

Temperature coefficient of disinfection of $B$. typhosus with hot water (end-point method).

$\begin{array}{cc}\begin{array}{c}\text { Temp. } \\ \text { of exp., } \\ \text { o } \mathrm{C} .\end{array} & \begin{array}{r}\text { Tim } \\ \text { taken } \\ \text { disinfec } \\ \text { minute }\end{array} \\ 59 & 1.2 \\ 54 & 22.5 \\ 49 & 196 \\ 57 & 7 \cdot 5 \\ 52 \cdot 1 & 53\end{array}$

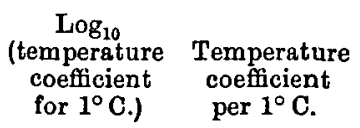

Exp. I, 10. 6. '09 $1 \cdot 26$

$\log _{10} t$ for $1^{\circ} \mathrm{C}$.) per $1^{\circ} \mathrm{C}$.

\begin{tabular}{|c|c|}
\hline 250 & $1 \cdot 78$ \\
\hline •188 & 1.54 \\
\hline 173 & $1 \cdot 46$ \\
\hline Mean & $1 \cdot 60$ \\
\hline
\end{tabular}

\footnotetext{
* Strictly speaking, reduction of about $5,000,000$ per c.c. to less than about 12 per c.c.
} 


\section{B. coli commune and Staphylococcus pyogenes aureus.}

In the preceding experiments with B. coli commune and Staph. py. aur. there are a few sets which can be used for calculation of the temperature coefficient of disinfection by hot water, assuming the effect of temperature to be consistent and in accordance with a logarithmic law. These are collected in Table XXII. Both species are extremely variable, and it is necessary, even more than was the case with B. typhosus, that for comparison of disinfection rate at different temperatures the experiments should be carried out on the same day, with the same material, etc. In Table XXII, for example, it will be seen that whereas on two occasions velocity constants obtained for the disinfection of $B$. coli at practically the same temperatures are very different, the temperature coefficients reckoned from them are very similar, 1.23 and 1.32 per $1^{\circ} \mathrm{C}$.

\section{TABLE XXII,}

Temperature coefficient of disinfection by hot water, B. coli commune and Staphylococcus pyogenes aureus.

\begin{tabular}{|c|c|c|c|c|c|}
\hline & Organism & $\begin{array}{c}\text { Temp., } \\
{ }^{\circ} \mathrm{C} .\end{array}$ & $\begin{array}{c}\text { Difference } \\
\text { in temp., } \\
{ }^{\circ} \mathrm{C} .\end{array}$ & $\begin{array}{l}\text { Mean value } \\
\text { of velocity } \\
\text { constant, } K\end{array}$ & $\begin{array}{l}\text { Temp. } \\
\text { coefficient } \\
\text { per } 1^{\circ} \mathrm{C} .\end{array}$ \\
\hline $\begin{array}{c}\text { ExP. 15. 2. '10 } \\
\text { (Table XII) }\end{array}$ & $\begin{array}{c}\text { B. coli commune } \\
\text {," }\end{array}$ & $\begin{array}{l}48 \cdot 9 \\
52 \cdot 7\end{array}$ & $3 \cdot 8$ & $\begin{array}{l}\cdot 172 \\
\cdot 381\end{array}$ & $1 \cdot 23$ \\
\hline $\begin{array}{c}\text { Exp. 26. 2.'10 } \\
\text { (Table XIII) }\end{array}$ & $\begin{array}{c}\text { B. coli commune } \\
, "\end{array}$ & $\begin{array}{l}49 \\
52 \cdot 5\end{array}$ & $3 \cdot 5$ & $\begin{array}{l}\cdot 0424 \\
\cdot 111\end{array}$ & $1 \cdot 32$ \\
\hline $\begin{array}{l}\text { Exp. 24. 1. '10 } \\
\text { (Table XVIII) }\end{array}$ & $\begin{array}{c}\text { Staph. py. aur. } \\
,,\end{array}$ & $\begin{array}{l}48 \cdot 9 \\
52 \cdot 9\end{array}$ & $4 \cdot 0$ & $\begin{array}{l}\cdot 0486 \\
\cdot 188\end{array}$ & $1 \cdot 40$ \\
\hline
\end{tabular}

The temperature coefficient of disinfection with hot water considerably exceeds that of disinfection by other means. Disinfection of B. paratyphosus with phenol and other coal-tar disinfectants was found to have a temperature coefficient of 10 per $10^{\circ} \mathrm{C}$. under certain conditions, while with metallic salts the figure was very much lower and approximated to that usually obtaining in chemical reactions. Disinfection by drying has also a low temperature coefficient, viz. 2 to 3 for $10^{\circ} \mathrm{C}$. (Paul, 1909 and Paul, Birstein and Reuss, 1910). In the case of disinfection by hot water we have figures ranging from about 136 per $10^{\circ} \mathrm{C}$. (1.635 per $1^{\circ} \mathrm{C}$., if we take the mean of the values obtained by the two different methods) in case of B. typhosus, to 29 per $10^{\circ} \mathrm{C}$. $\left(1.40\right.$ per $1^{\circ} \mathrm{C}$.) in case of Staphylococcus and 12 per $10^{\circ} \mathrm{C} .\left(1 \cdot 28\right.$ per $1^{\circ} \mathrm{C}$.) in case of B. coli. 
The figures in cases like that of B. coli and Staph. py. aur., where data are scanty, must only be considered approximate. The bigh temperature coefficient makes experiment impossible except over a very small range of temperature, and one can only obtain the effect for $10^{\circ} \mathrm{C}$. by calculation; a small error, therefore, in the value obtained for $1^{\circ} \mathrm{C}$. will lead to a large one when this value is raised to the 10th power to obtain the value for $10^{\circ} \mathrm{C}$. rise in temperature.

\section{(4) Influence of acids and alkalis.}

The influence of reaction upon disinfection by hot water was noticed in the course of some experiments in which a suspension of $B$. typhosus in broth was the material used for investigation. The experiments were made in order to obtain information which might be of service in the manufacture of vaccines. The temperature was $54^{\circ} \mathrm{C}$. The method of experiment was exactly as in the preceding experiments, except that, in place of distilled water, the bacteria were suspended in broth in which the same species had grown for 40 hours at $37^{\circ} \mathrm{C}$. and which had been sterilised by filtration through a Berkefeld filter.

Disinfection was logarithmic, but the rate was much slower than in distilled water under the same conditions. This was found to be due to the slight alkalinity of the broth. On addition of a small quantity of acid $\left(0 \cdot 25\right.$ c.c. $\frac{N}{1}$ acetic acid to 20 c.c. broth) up to neutralisation point (litmus), the rate of disinfection was increased about 8 times, see Table XXIII, Experiments of 22. 7. '09 and Fig. 20. A small extra amount of acid, too small to exert any disinfectant action of itself ${ }^{1}$ (in all 0.5 c.c. $\frac{\mathrm{N}}{\mathrm{l}}$ acetic acid added to 20 c.c. broth), rendered disinfection so quick that its rate could not be measured, see Table XXIV, Experiment II. In this case, the value of the velocity constant of disinfection

1 Acetic acid in the presence of $1 \%$ peptone has been shown to exert a disinfectant action upon $B$. coli conmune at and above a concentration of $\frac{N}{11}$ (Winslow and Lockridge, 1906). B. typhosus is probably more susceptible, but in the above case $\left(0.25\right.$ c.c. $\frac{N}{1}$ acetic acid to $20 \cdot 25$ c.c. neutralised broth) it is likely that the acidity of the medium fell far short of $\frac{\mathrm{N}}{100}$. The broth contained besides $1 \%$ peptone, a considerable proportion of meat extractives, which also, by combining with the acid added, would tend to further reduce the concentration of free acid in the medium. 


\section{TABLE XXIII.}

Effect of small differences in reaction upon the disinfection of

$B$. typhosus in broth at $54 \cdot 1^{\circ} \mathrm{C}$.

Exp. I, 22. 7. '09. Medium = filtered culture $\left(40 \mathrm{hrs.}\right.$ at $37^{\circ} \mathrm{C}$.) of B. typhosus.

\begin{tabular}{|c|c|c|c|c|c|c|c|}
\hline $\begin{array}{l}\text { Time, } \\
\text { minutes } \\
=t\end{array}$ & $\begin{array}{l}\text { Amount } \\
\text { of } \\
\text { sample } \\
\text { plated, } \\
\text { drops }\end{array}$ & $\begin{array}{l}\text { Numbers } \\
\text { counted } \\
\text { on plates } \\
\text { (agar) }\end{array}$ & Mean & $\begin{array}{l}\text { Mean no. of } \\
\text { bacteria present } \\
\text { in } 1 \text { drop } \\
\text { disinfection } \\
\text { mixture, }=N\end{array}$ & $\log _{10} N$ & $\frac{1}{t_{n}}$ & $\begin{array}{l}K= \\
t_{0} \log \frac{N_{0}}{N_{n}}\end{array}$ \\
\hline $0.32=t_{0}$ & 1 & $2796 \quad 2888 \quad 2954$ & 2879 & $2879=N_{0}$ & $3 \cdot 459$ & & - \\
\hline $1 \cdot 07$ & 1 & $1704 \quad 1982 \quad 1894$ & 1860 & 1860 & $3 \cdot 270$ & & $\cdot 25$ \\
\hline $2 \cdot 15$ & 2 & $\begin{array}{lll}1160 & 1029 & 1187\end{array}$ & 1125 & 562 & $2 \cdot 750$ & & 39 \\
\hline $3 \cdot 50$ & 3 & $\begin{array}{lll}565 & 573 & 504\end{array}$ & $547 \cdot 3$ & $182 \cdot 4$ & $2 \cdot 261$ & & $\cdot 38$ \\
\hline & 5 & 157 & -1 & & & & \\
\hline $6 \cdot 00$ & $\{9$ & 339 & $-?$ & $38 \cdot 1$ & $1 \cdot 581$ & & $\cdot 33$ \\
\hline \multirow{3}{*}{$10 \cdot 00$} & 10 & 418 & - & & & & \\
\hline & $\{10$ & $20 \quad 20$ & -1 & 1.62 & $\cdot 209$ & & $\cdot 34$ \\
\hline & & & & & \multicolumn{2}{|c|}{ Mean } & .34 \\
\hline
\end{tabular}

Exp. II, 22. 7. '09. Medium = neutralised filtered culture $\left(40 \mathrm{hrs}\right.$. at $37^{\circ} \mathrm{C}$. $)$ of $B$. typhosus (10 drops $=0.25$ c.c. $\frac{N}{1}$ acetic acid added to 20 c.c. broth).

\begin{tabular}{lrrrrcccc}
$0.28=t_{0}$ & 1 & 590 & 602 & 679 & 624 & $624=N_{0}$ & $2 \cdot 795$ & - \\
0.53 & 1 & 154 & 36 & 266 & 152 & 152 & $2 \cdot 182$ & $2 \cdot 45$ \\
1.0 & 3 & 40 & 19 & 40 & 33 & 11 & 1.041 & 2.44 \\
1.5 & 3 & 2 & 0 & 0 & 0.66 & 0.22 & -.658 & $2 \cdot 83$ \\
\cline { 3 - 7 } & & & & & & & & \\
& & & & & & & &
\end{tabular}

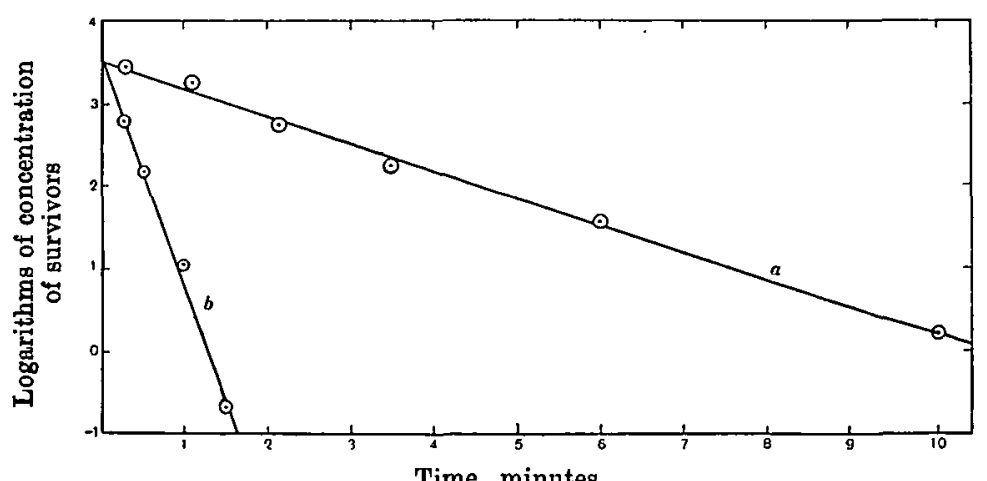

Fig. 20. Effect of reaction upon disinfection of $B$. typhosus in broth at $54 \cdot 1^{\circ} \mathrm{C}$. (Table XXIII).

(a) Exp. I, broth slightly alkaline.

(b) Exp. II, broth made just neutral (litmus) with acetic acid. 
in the original broth was 0.44 ; in the faintly acid broth, where about 3000 organisms per drop were reduced to less than 1 per drop in 15 seconds, the value of the velocity constant was more than 17.6 , i.e. more than 40 times as great as in the original.

\section{TABLE XXIV.}

Effect of small differences in reaction upon the disinfection of $B$. typhosus in broth at $54^{\circ} \mathrm{C}$.

Exp. I, 24. 7. '09. Medium $=$ filtered culture $\left(40\right.$ hrs. at $37^{\circ}$ C. $)$ B. typhosus.

\begin{tabular}{|c|c|c|c|c|c|c|c|}
\hline $\begin{array}{l}\text { Time, } \\
\text { minutes } \\
\quad=t\end{array}$ & $\begin{array}{l}\text { Amount } \\
\text { of } \\
\text { sample } \\
\text { plated, } \\
\text { drops }\end{array}$ & $\begin{array}{c}\text { Numbers } \\
\text { counted } \\
\text { on plates } \\
\text { (agar) }\end{array}$ & Mean & $\begin{array}{l}\text { Mean no. of } \\
\text { bacteria present } \\
\text { in } 1 \text { drop } \\
\text { disinfection } \\
\text { mixture, }=N\end{array}$ & $\log _{\mathbf{J} 0} N$ & & $\frac{1}{-t_{0}} \log \frac{N_{0}}{\bar{N}_{n}}$ \\
\hline $0.27=t_{0}$ & 1 & $2640 \quad 2816 \quad 3232$ & 2896 & $2896=N_{0}$ & $3 \cdot 462$ & & - \\
\hline 0.98 & 1 & $2068 \quad 1420 \quad 1754$ & 1747 & 1747 & $3 \cdot 242$ & & $\cdot 31$ \\
\hline $2 \cdot 00$ & 1 & $\begin{array}{lll}165 & 240 \quad 325\end{array}$ & 243 & 243 & $2 \cdot 386$ & & $\cdot 62$ \\
\hline $3 \cdot 53$ & 3 & $357 \quad 351$ & 354 & 118 & $2 \cdot 072$ & & $\cdot 43$ \\
\hline $6 \cdot 17$ & 5 & $59 \quad 40$ & $49 \cdot 5$ & $9 \cdot 9$ & $\cdot 996$ & & $\cdot 42$ \\
\hline $10 \cdot 27$ & $\left\{\begin{array}{l}10 \\
20\end{array}\right.$ & ${ }_{1}{ }_{1}{ }^{3}$ & $-\}$ & 0.125 & -.903 & & -44 \\
\hline & & & & & \multicolumn{2}{|c|}{ Mean } & $\cdot 44$ \\
\hline
\end{tabular}

Exp. II, 24. 7. '09. Medium = filtered culture $\left(40\right.$ hrs. at $37^{\circ} \mathrm{C}$.) B. typhosus +20 drops $(0.5$ c.e. $) \frac{N}{1}$ acetic acid to 20 c.c. broth.

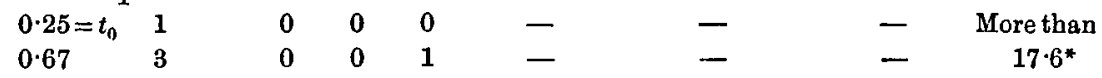

* In Exp. II, disinfection after 0.25 minutes is more complete than after 10.27 minutes in Exp. I, i.e. disinfection rate is more than 40 times that of Exp. I, $K=$ more than 17·6.

For the sake of comparison with the above experiments were made to investigate the influence of reaction upon disinfection in distilled water. In Tables XXV and XXVI are set forth the results of two comparable sets of experiments, in which $B$. typhosus was heated at $54^{\circ} \mathrm{C}$. in water to which were added various small amounts of acid and alkali insufficient in themselves to exert a disinfectant action. The smallest amounts which were employed were sufficient to render the solutions acid or alkaline to the extent of $\frac{1}{7000}$ th $N$ respectively. In the case in which alkali was added, the solution was just alkaline to phenol phtbalein. These small amounts were not without effect

1 Death rate at $20^{\circ} \mathrm{C}$. of $B$. typhosus suspended in water containing a concentration of $\mathrm{H}_{2} \mathrm{SO}_{4}=\frac{\mathrm{N}}{500}$ was found to be insignificant. Disinfection by $\mathrm{H}_{2} \mathrm{SO}_{4}$ may be assumed to have a low temperature coefficient from analogy with other mineral disinfectants. 
upon the rate of disinfection by hot water, which in the case of alkali was increased about 1.5 to 2.0 times, and in the case of acid 5 to 7 times. On further addition of acid disinfection became too quick to study, whereas the increase in rate on adding more alkali was comparatively slight.

It therefore follows that, in the preparation of vaccines, no conclusion drawn from one set of experiments can be usefully applied to another set, unless the composition and reaction of the medium, in which the bacteria are heated, be kept strictly constant. This is almost impossible for, in the case of broth cultures, the reaction of the broth will, within small limits, depend upon the extent of the growth of organisms. It is not possible to control this, and small differences arising therefrom will have a very significant influence upon the rate of destruction by heat of the organisns suspended in the medium.

\section{TABLE XXV.}

Effect of small amount of acid and alkali upon disinfection of B. typhosus in distilled water at $54^{\circ} \mathrm{C}$.

Exp. 4. 8. '09. Distilled water.

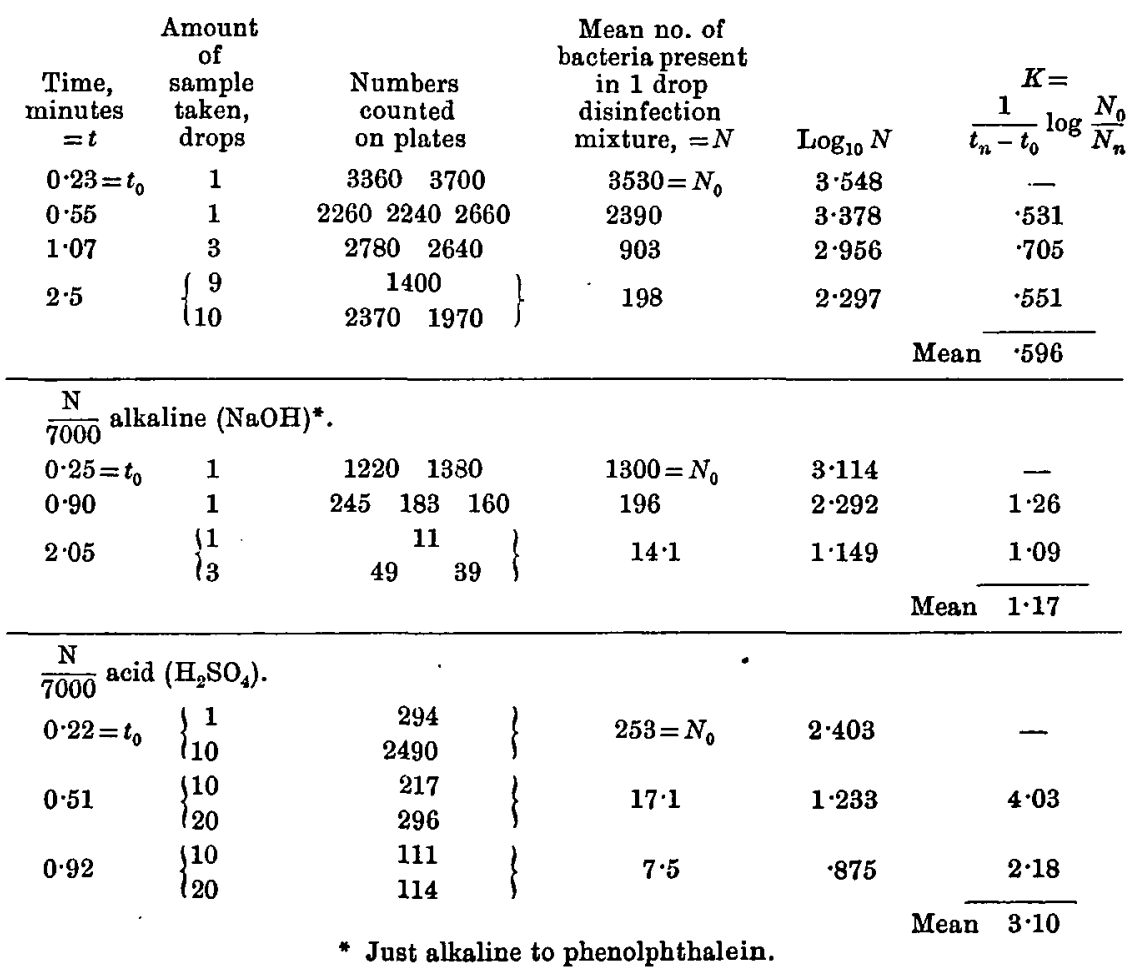




\section{TABLE XXVI.}

Effect of small amount of acid and alkali upon disinfection of B. typhosus in distilled water at $52^{\circ} \mathrm{C}$.

Exp. I, 19. 8. '09. Distilled water.

\begin{tabular}{|c|c|c|c|c|c|}
\hline $\begin{array}{l}\text { Time, } \\
\text { minutes } \\
=t\end{array}$ & $\begin{array}{l}\text { Amount } \\
\text { of } \\
\text { sample } \\
\text { taken, } \\
\text { drops }\end{array}$ & $\begin{array}{l}\text { Numbers } \\
\text { counted } \\
\text { on plates }\end{array}$ & $\begin{array}{l}\text { Mean no. of } \\
\text { bacteria present } \\
\text { in } 1 \text { drop } \\
\text { disinfection } \\
\text { mixture, }=N\end{array}$ & $\log _{10} N$ & $\begin{array}{c}K= \\
\frac{1}{t_{n}-t_{0}} \log \frac{N_{0}}{N_{n}}\end{array}$ \\
\hline $0 \cdot 33=t_{0}$ & 1 & $\begin{array}{llll}7250 & 5420 & 5350\end{array}$ & $6010=N_{0}$ & $3 \cdot 779$ & $1 \cdot 65$ \\
\hline $1 \cdot 0$ & 3 & $7850 \quad 5500$ & 2225 & $3 \cdot 347)$ & \\
\hline
\end{tabular}

ExP. II. $\frac{\mathrm{N}}{7000}$ alkaline $(\mathrm{NaOH})^{*}$.

$0 \cdot 33=t_{0} \quad 2 \quad 693062307550$

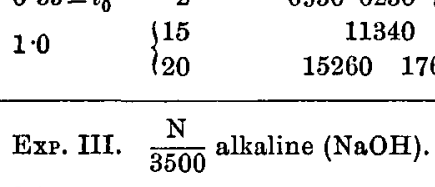

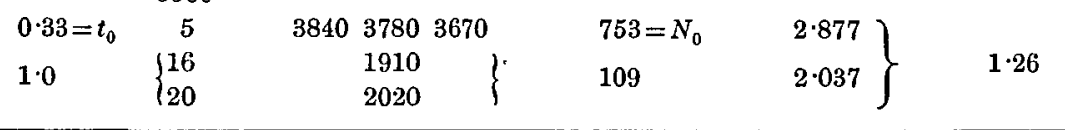

Exp. IV. $\frac{N}{1750}$ alkaline $(\mathrm{NaOH})$.

\begin{tabular}{|c|c|c|c|c|c|}
\hline $0 \cdot 33=t_{0}$ & 10 & 61807860 & 8780 & $761=N_{0}$ & $2 \cdot 881$ \\
\hline $1 \cdot 0$ & $\left\{\begin{array}{l}19 \\
90\end{array}\right.$ & 1780 & 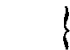 & 111 & $2 \cdot 045$ \\
\hline
\end{tabular}

Exp. V. $\frac{\mathrm{N}}{875}$ alkaline (NaOH).

\begin{tabular}{|c|c|c|c|c|}
\hline $0 \cdot 33=t_{0}$ & $\left\{\begin{array}{l}16 \\
00\end{array}\right.$ & $\begin{array}{r}9250 \\
1870\end{array}$ & $587=N_{0}$ & $2 \cdot 769$ \\
\hline & 19 & 1600 & 78.5 & 1.805 \\
\hline 1.0 & $\{20$ & 1460 & 100 & 1.890 \\
\hline
\end{tabular}

Exp. VI. Distilled water.

\begin{tabular}{|c|c|c|c|c|c|}
\hline $0 \cdot 33=t_{0}$ & 1 & $930 \quad 10201130$ & $1030=N_{0}$ & $3 \cdot 013$ & \\
\hline 1.0 & $\left\{\begin{array}{l}3 \\
5\end{array}\right.$ & $\left.\begin{array}{cc}760 & 1280 \\
2280\end{array}\right\}$ & 393 & $2 \cdot 594$ & $\cdot 62$ \\
\hline
\end{tabular}

ExP. VII. $\frac{\mathrm{N}}{7000}$ acid $\left(\mathrm{H}_{2} \mathrm{SO}_{4}\right)$.

$\left.\begin{array}{lrrrrrr}0.33=t_{0} & 5 & 179 & 179 & & 35 \cdot 8=N_{0} & 1.554 \\ 1.0 & 20 & (?) 2 & 0 & (?) 0.05 & (?)-1.301\end{array}\right\}$ at least $4 \cdot 29$

* Just alkaline to phenolphthalein. 
(5) Analogy between the disinfection of bacteria by hot water and the "heat coagulation" of proteins.

The disinfection of bacteria by heat in presence of water exhibits a striking analogy with the behaviour of some proteins under similar conditions, and leads to the inference that disinfection of bacteria by this means is due to hydration of their constituent proteins.

The suggestion has already been made that the difference in resistance to heat of vegetative and sporing forms is caused by the difference in the readiness with which their respective proteins are coagulated (Lewith, 1890, Hewlett, loc. cit. p. 20). Lewith (p. 349) adduces some experimental support for the view that this difference is to be attributed to a diminution in the water-content of spores. That coagulation is not a pure temperature effect is clear from the comparative security of both bacterial spores and proteins at high temperatures in the absence of water.

The analogy takes a more definite shape when the foregoing experiments with bacteria are compared with some recent work on the alteration of proteins by hot water.

Famulener and Madsen (1908) found that the destruction of three antigens when heated in the presence of water proceeded logarithmically and that the process had a very high temperature coefficient, being about 2 for a rise in temperature of $1^{\circ} \mathrm{C}$. A similar set of results have been obtained by Madsen and Streng (1909) for a series of agglutinins.

The "heat coagulation of" two pure crystallised proteins, haemoglobin and egg-albumen, has recently been shown (Chick and Martin, 1910) to be an orderly time-process, the rate of which varies with alteration of temperature, reaction and other conditions. In the case of haemoglobin coagulation takes place logarithmically, the coagulation rate at any moment being proportional to the concentration of uncoagulated protein. In the case of crystallised egg-albumen the reaction is of a higher order, as the crystals consist of a series of salts of protein with the acid used in their preparation, which salts coagulate at different rates. The effect of temperature upon the rate of reaction was found to be unusually great, the temperature coefficient in the case of haemoglobin being 1.3 per degree centigrade, and, in the case of egg-albumen, 1.91 per degree centigrade. 
These observations on proteins show that it is improper to speak of a protein as having a definite "coagulation temperature"; for the same reason, it is no longer permissible to talk of the "thermal death-point" of any particular species of bacteria. It is in both cases the possession of exceedingly high temperature coefficients which have rendered observation of these supposed constants of any practical value. This will be clear from some such example as the following. In the case of disinfection of $B$. typhosus with hot water, the temperature coefficient has been determined to be 1.635 for $1^{\circ} \mathrm{C}$. rise in temperature. From the value of velocity constant in Table $X, 0.111$, it can be calculated that a suspension of $B$. typhosus, containing 100,000 bacteria per c.c., would be disinfected (the number reduced to less than 1 , an average of 0.5 , per c.c.) in 48 minutes at $49^{\circ} \mathrm{C}$. From the above value of the temperature coefficient it can be calculated that the disinfection would take about 2 hours at $47^{\circ}, 18$ minutes at $51^{\circ} \mathrm{C}, 7$ minutes at $53^{\circ}, 2 \frac{1}{2}$ minutes at $55^{\circ}$ and 21 seconds at $59^{\circ}$. If, therefore, a suspension of $B$. typhosus in water were gradually heated up, death would apparently take place suddenly at a temperature near $55^{\circ} \mathrm{C}$, and it is easy to understand how some such temperature should come to be regarded as the "thermal death-point" for this species.

Another point of analogy between the "heat coagulation" of proteins and disinfection of bacteria by hot water is that both processes are similarly affected by the presence of minute quantities of acid, the rate being greatly increased in each case.

The striking similarity between the effects of temperature (dry) on the one band, and hot water on the other indicate that disinfection by the latter is due to the action of water (coagulation or alteration) upon some one protein which is essential for the life of the bacterium, and that the character of the reaction is conditioned by the chemical action of water upon its constituent proteins.

\section{(6) Summary of Section III.}

1. (a) In the case of B.typhosus, B. coli commune, and B. pestis disinfection with hot water also proceeds according to a logarithmic law, the rate of disinfection at any moment being proportional to the concentration of surviving bacteria.

(b) In the case of $B$. paratyphosus the rate of disinfection at the beginning of the experiments was in excess of the theoretical, but in the course of a few minutes slowed down to a consistent rate. The same 
phenomenon had previously been observed in disinfection of this species with phenol and other disinfectants.

(c) In the case of Staphylococcus there was the greatest variability in the character of the disinfection process, which in some cases conformed to the ideal type (anthrax spores or B. typhosus), in others to that of $B$. paratyphosus, while in others again there was a period of "lag" at the beginning of disinfection recalling disinfection of Staphylococcus with phenol. Further complications were introduced by the lack of constancy in resistance to disinfecting agents which is characteristic of this species.

2. The effect of difference in temperature upon rate of disinfection by bot water has been shown to be consistent throughout the small range investigated and in accordance with the law of Arrhenius, or some similar logarithmic law. The temperature coefficient has been determined in some cases, and in that of $B$. typhosus reaches the high figure of 1635 per $1^{\circ} \mathrm{C}$, or 136 per $10^{\circ} \mathrm{C}$. In the case of B. coli commune and Staphylococcus pyogenes aureus, the temperature coefficient was not studied with the same completeness but, from the few observations made, appears to be 1.28 and 1.4 respectively per degree centigrade.

The high temperature coefficient is comparable to that obtained for precipitation of proteins with hot water, and supports the view that disinfection of bacteria by this means is due to "heat coagulation" of their constituent proteins.

3. The presence of minute quantities of acid or alkali too small to produce any direct disinfectant action has a very marked influence upon disinfection by hot water. In both cases the rate of disinfection is increased, but in the case of acid to a much greater extent. Whereas, in the case of $B$. typhosus, the addition to distilled water of sufficient alkali to render the solution $\frac{\mathrm{N}}{7000}$ alkaline increased the mean rate of disinfection at $54^{\circ} \mathrm{C}$. about 1.5 - to 2 -fold, a similar addition of acid increased it 5- to 7 -fold. Further addition of alkali influenced the disinfection-rate comparatively little; with further addition of acid it became too rapid for study. This presents a close analogy with the influence of small quantities of acid upon "heat coagulation" of proteins.

4. The effect of reaction was of the same order when suspensions of bacteria in broth were substituted for those in water. For this reason it is impossible to obtain standard conditions in the manufacture of vaccines, as owing to the growth of the bacteria it is impossible to control the reaction of the broth. 


\section{Disinfectant action of SUnlight and DRying.}

Sunlight. The only suitable data upon this subject, which are available, are the results of some experiments by Clark and Gage (1903) in which the disinfectant action of sunlight was quantitatively studied upon B. typhosus and B. coli commune suspended in water. Most of the experiments give irregular results from which no conclusion can be drawn. In Table XXVII, however, are set forth the results of one experiment with $B$. coli which gives consistent results and which well repays analysis. The concentration of survivors, determined from time to time

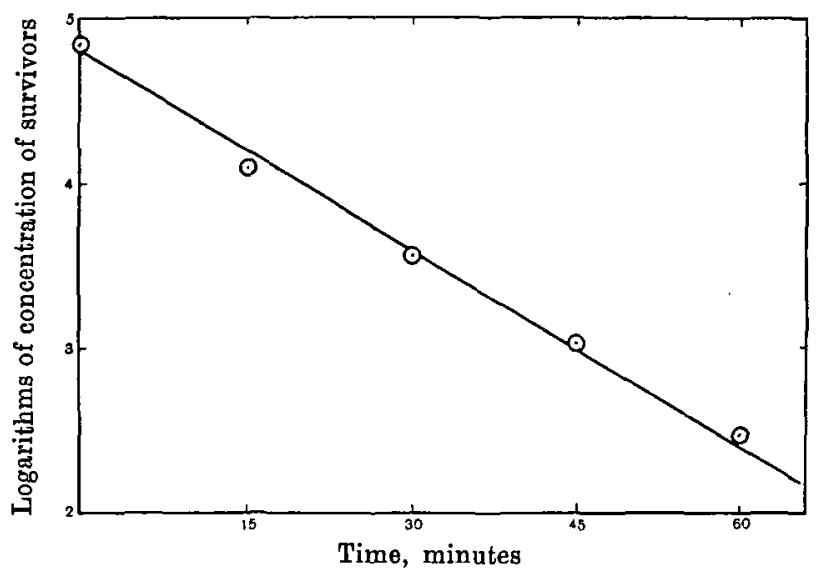

Fig. 21. Disinfection of $B$, coli commune by sunlight, results of Clark and Gage (1903), Table XXVII.

\section{TABLE XXVII.}

Disinfectant action of sunlight upon B. coli commune.

(Clark and Gage, Thirty.fourth Annual Report, State Board of Health, Massachusetts, 1903.)

$\begin{array}{cccc}\begin{array}{c}\text { Time, } \\ \text { minutes } \\ =t\end{array} & \begin{array}{c}\text { Concentration of } \\ \text { surviving bacteria, } \\ \text { numbers per c.c. }=N\end{array} & \log _{10} C & \frac{1}{t_{n}-t_{0}} \log \frac{N_{0}}{N_{n}} \\ 0=t_{0} & 71400=N_{0} & 4 \cdot 854 & - \\ 15 & 12365 & 4 \cdot 092 & \cdot 051 \\ 30 & 3568 & 3 \cdot 566 & .043 \\ 45 & 1065 & 3.027 & .041 \\ 60 & 295 & 2 \cdot 470 & \cdot 040 \\ & & & \text { Mean } \frac{.044}{-}\end{array}$


by means of plate cultures, is seen to vary logarithmically with time, the value of the velocity constant, $K$, remains fairly constant in value, and a straight line is obtained when logarithms of concentration of survivors are plotted against time, see Fig. 21.

It is not justifiable to draw a definite conclusion from such scanty data, but it is more than probable, judging from analogy, that the process of disinfection by sunlight will be found to fall in line with that experimentally established for other agents.

Drying. In a preliminary examination of the suitability of the garnet $^{1}$ method for investigating the action of disinfectants upon Staphylococcus, Paul and Prall (1907) allowed garnets, coated with a thin dry film of this species, to remain at various temperatures and counted the surviving bacteria from time to time. At the temperature of liquid air the number of living bacteria remained roughly constant for many weeks, at ordinary temperature the number slowly decreased. Paul (1909) has recently analysed these data and shown that death-in this instance by drying-occurs in accordance with a logarithmic law and that the temperature coefficient for the process is about $2-3$ for $10^{\circ} \mathrm{C}$. rise in temperature (see also Paul, Birstein and Reuss, 1910).

\section{Summary and General Conclusions.}

1. The additional experimental evidence brought forward in the present paper lends further support to the view already put forward (1908) that disinfection is an orderly time-process, which may be considered analogous with a chemical reaction, viz. a reaction between the bacterium on the one hand, and the disinfectant on the other. In the ideal case disinfection proceeds in accordance with some rule analogous to the Mass Law, so that if the disinfectant is present in large excess, disinfection rate at any moment is proportional to the concentration of the bacteria $\left(-\frac{d n}{d t}=K n\right.$, where $n$ is the concentration of bacteria at the time $t$, and $K$ is a constant depending on the temperature, concentration of disinfectant, etc.).

2. The above view was originally put forward on the basis of experiments with anthrax spores and $B$. paratyphosus, using a series of

1 Krönig and Paul (1897).

Journ. of Hyg. x 
different disinfectants (H. C. 1908). In the present paper the results of further experiments with phenol are given in confirmation, viz. with B. typhosus, B. coli commune and Staphylococcus pyogenes aureus.

3. Disinfection with phenol and other disinfectants has already (loc. cit.) beeu shown to be influenced by temperature in accordance with the Law of Arrhenius. The effect upon disinfection rate of alteration in concentration of disinfectant (loc. cit. p. 117, and H. E. Watson, 1908) is also in accord with the view expressed in 1 .

4. Further confirmation has been obtained from the case of destruction of bacteria by hot water between the temperatures of $45^{\circ} \mathrm{C}$. and $55^{\circ} \mathrm{C}$. Investigations on this subject are described in the present paper, and a very impressive parallel shown to exist between this case of disinfection and the heat coagulation of proteins. Both are consistent timeprocesses proceeding in uncomplicated cases in accordance with the Mass Law, influenced consistently by change of temperature in agreement with the Law of Arrhenius, and both possessing an extraordinarily high temperature coefficient. Both are similarly influenced by addition of minute quantities of acid.

The organisms worked with were B.typhosus, B. coli commune, B. paratyphosus, Staphylococcus pyogenes aureus and B. pestis.

5. Disiufection by drying (Paul, 1909) and, as far as can be judged from very scanty data (Clark and Gage, 1903), by sunlight fall into line with the other cases of disinfection which have been investigated.

The facts relating to the disinfection process have not been questioned, but some amount of criticism has been aroused by the explanation which has been suggested on the following lines.

As regards disinfection (whether by "disinfectants," hot water, sunlight, drying) a culture of bacteria consists of a uniform population. The fact that the individuals do not die all at once but at a rate proportional to the concentration of the survivors at a given moment is to be attributed to temporary and rhythmical changes in resistance which, by analogy with chemical processes, may be supposed to be due to temporary energy changes of the constituent proteins.

This simple law has been found to express the relation of mortality to time for the germicidal action of chemical disinfectants and heat upon anthrax spores and very closely, in my experiments, upon B. typhosus, B. coli and Staphylococcus (phenol). The deviation or departure from the law, most marked in the case of $B$. paratyphosus, 
has in my experience always been in one direction', viz. the rate of destruction falls more quickly than would be accounted for by the change in concentration of survivors alone. Here too, I believe the rate to be determined by concentration but to be complicated by the individual bacteria possessing more or less permanent differences in resistance.

Hewlett (loc. cit.) and Reichel (1909, p. 152) consider that the progressive nature of disinfection can be more naturally explained by supposing it to be due to differences in resistance occurring among the various bacteria ${ }^{2}$. If such were the case, disinfection would certainly be gradual and not sudden, but the rate would only be proportional to the concentration of survivors if the different resistances were allotted according to one definite arrangement, an arrangement which could only occur as a remote coincidence, and could hardly be universally present. For, suppose that the disinfection of 100,000 bacteria is in question, that the survivors vary logarithmically with time, as in the ideal case of disinfection, and that for the sake of argument the rate happens to be a reduction to $\frac{1}{10}$ th in each minute,

$$
\begin{aligned}
10,000 & =\frac{1}{10} \text { of } 100,000, \text { survive after } 1 \text { minute, } \\
1000 & =\frac{1}{10} \text { of } 10,000, \text { will survive after } 2 \text { minutes, and } \\
100 & =\frac{1}{10} \text { of } 1000, \text { will survive after } 3 \text { minutes, } \\
10 & =\frac{1}{10} \text { of } 100, \text { will survive after } 4 \text { minutes, and so on. }
\end{aligned}
$$

If the cause of this is to be sought in the possession by the bacteria of different individual resistances to disinfection we should have to suppose that these resistances had the following distribution among the 100,000 bacteria, viz. that

$$
\begin{aligned}
& 90,000 \text { take } 1 \text { minute to kill, } \\
& 9000 \text { take } 2 \text { minutes to kill, } \\
& 900 \text { take } 3 \text { minutes to kill, } \\
& 90 \text { take } 4 \text { minutes to kill, and so on. }
\end{aligned}
$$

\footnotetext{
1 Cases in which departure from the logarithmic law is in the direction of preliminary lag may be explained by supposing it to be due to a delay in the disinfectant getting to work; after such delay disinfection usually proceeds in the ideal way, disinfection being proportional to the concentration of survivors (see disinfection of Staphylococcus, p. 244).

- A similar view was expressed by Bellei (1904).
} 
Or, in the general case, if $N$ bacteria die logarithmically, and if $\frac{1}{x}$ of $N$ survive 1 minute, then

$$
\begin{aligned}
& \frac{1}{x^{2}} N \text { will survive } 2 \text { minutes, } \\
& \frac{1}{x^{3}} N \text { will survive } 3 \text { minutes, and so on, }
\end{aligned}
$$

and the resistance of the various individuals will be so distributed that there are present

$$
N-\frac{N}{x}, \text { or } N \frac{(x-1)}{x} \text {, which are killed in } 1 \text { minute, }
$$

$N\left(\frac{x^{2}-1}{x^{2}}-\frac{x-1}{x}\right)$, or $N \frac{(x-1)}{x^{2}}$, which take 2 minutes to kill,

$N\left(\frac{x^{3}-1}{x^{3}}-\frac{x-1}{x^{2}}-\frac{x-1}{x}\right)$, or $N \frac{(x-1)}{x^{3}}$, which take 3 minutes to kill, and no other distribution will satisfy the necessary condition.

A further argument can be brought against a theory of variable permanent resistance, viz. that a chance characteristic is as a rule distributed in a different manner. Those individuals possessing it in moderate amount are usually in the greatest number, while those possessing it in greater or less degree are in the minority. In the case of disinfection, those apparently possessing the least resistance are invariably in the greatest number.

A more rational explanation is based upon the essential similarity of the individual bacteria, for in no other way can the logarithmic nature of disinfection in the ideal case be reasonably accounted for. If one condition be necessary for death, or a multitude of small causes, among a number of similar individuals, the result to be governed by the law of probability, death will occur logarithmically (see Yule, 1910). In order to obtain a mental picture of the disinfection process, one is led to seek an analogy with other processes, which also occur logarithmically, viz. chemical reactions of the first order such as the decomposition of hydrogen arsenide, the inversion of sugar and, under certain conditions, the "heat coagulation" of proteins. The closest possible analogy has been shown to exist between the last instance and the destruction of bacteria by hot water. In these cases an explanation has been sought in temporary changes in the energy of the molecules, as a consequence of which all molecules do not possess the same sensibility to attack at the same moment. Some such property is therefore attributed to the 
molecules (or aggregates of molecules) of the constituent protein of the bacteria, whereby at a given moment only a certain proportion is liable to attack; the amount being dependent upon the concentration at the moment of unaltered protein, in other words the number of bacteria ${ }^{1}$ surviving in unit volume.

Disinfection, whether by disinfectants or by heat, may be considered analogous to a chemical reaction the velocity of which is controlled by external conditions such as temperature or concentration of bacteria and disinfectant.

In conclusion, I gratefully acknowledge the great help I have received from Dr C. J. Martin, F.R.S., whose valuable advice and practical assistance have been at my disposal throughout this work. I am also indebted to bim for the design of the very convenient apparatus, shown in Fig. 8, used for investigating disinfection by hot water.

\section{BIBLIOGRAPHY.}

BeLleI (1904). Verbesserte Methode zur Bestimmung des Werthes von chemischen Desinfectionsmitteln. Münch. med. Wochenschr., No. 7.

Chick (1908). An Investigation of the Laws of Disinfection. Journ. of Hyg., vili. 92.

ChICK and Martin (1908). The Principles involved in the Standardisation of Disinfectants. Journ. of Hyg., vIIr, 655.

- (1910). On the "heat coagulation" of proteins. Journ. of Physiol., xL. 404.

ClarK and $\mathrm{G}_{\mathrm{AgE}}$ (1903). 34th Annual Report of the State Board of Health, Massachusetts.

Eijkman (1908). Die Ueberlebungskurve bei Abtötung der Bakterien durch Hitze. Biochem. Zeitschr., xr. 12.

- (2 T. II. 1909). Investigations on the subject of Disinfection. K. Acad. van Metenschappen te Amsterdam.

Famulener and Madsen (1909). Die Abschwächung der Antigene durch Erwärmung. Biochem. Zeitschr., xI. 186.

Hewlett (1909). Milroy Lectures on Disinfection and Disinfectants, reprinted from the Lancet (March 13, 20, and 27).

IkEDA (1897). Die chemische Grundlage der Lehre von der Giftwirkung und Desinfektion. Zeitschr. f. Hyg., xxv. 95.

KRöNIG and PAUL (1897). Die chemische Grundlage der Lehre von der Giftwirkung und Desinfektion. Zeitschr. $f$ Hyg., xxv. 1.

LEw ITH (1890). Ueber die Ursache der Widerstandsfähigkeit der Sporen gegen hohe Temperaturen. Arch.f. exper. Path. u. Pharm., xxvi. 341.

1 Disinfection is ordinarily arranged so that the disinfectant is present in large excess, and its concentration may be considered to remain constant during the process. 
Madsen and Nyman (1907), Zur Theorie der Desinfektion. Zeitschr. f. Hyg., Lvir. 388.

Madsex and Strexg (1909). Einfluss der Temperatur auf den Zerfall der Antikörper. Zeitschr. f. physikal. Chemie, Lxx. 263.

PAUL (1909). Der chemische Reaktionsverlauf beim Absterben trockener Bakterien bei niederen Temperaturen. Biochem. Zeitschr., xviII. 1.

Paul, Birstein and Reuss (1910). Beitrag zur Kinetik des Absterbens der Bakterien in Sauerstoff verschiedener Konzentration und bei verschiedenen Temperaturen. Biochem. Zeitschr., xxv. 367.

Padl and Prall (1907). Die Wertbestimmung von Desinfektionsmitteln mit Staphylococcen die bei der Temperatur der flüssigen Luft aufbewahrt wurden. Arb. a. d. Kaiserl. Ges.-amt, xxvI. 424.

Reichel (1909). Zur Theoric der Desinfektion. Biochem. Zeitschr., xxir. 149.

RIDEA L and WALKer (1903). The Standardisation of Disinfectants. Journ. of the Roy. San. Inst., xxIv. 424.

WinsLOW and LockRIDGE (1906). The toxic effect of certain acids upon typhoid and colon bacilli in relation to their degree of dissociation. Journ. of Infectious Diseases, IIr. 547.

Yule (1910). On the distribution of deaths with age when the causes of death act cumulatively, and similar frequency distributions. Journ. Roy. Statistical Soc., LxxIII. 